
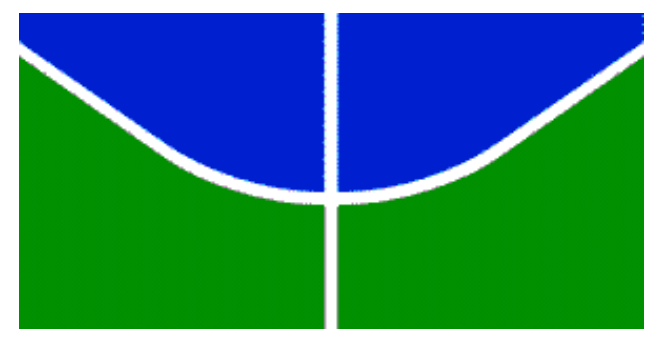

Universidade de Brasilia

Instituto de Letras

Departamento de Linguística, Português e Línguas Clássicas

Programa de Pós-Graduação em Linguística

REFLEXÃO LINGUÍSTICA, REVISÃO E REESCRITA TEXTUAL COMO FORMAS DE PROMOVER A CONSCIÊNCIA SINTÁTICA

Talita Gleycilane Mendes da Silva

Brasilia,

2017. 


\title{
REFLEXÃO LINGUÍSTICA, REVISÃO E REESCRITA TEXTUAL COMO FORMAS DE PROMOVER A CONSCIÊNCIA SINTÁTICA
}

Talita Gleycilane Mendes da Silva

\begin{abstract}
Dissertação apresentada como requisito para a obtenção do grau de mestre em linguística no Programa de Pós-Graduação em Linguística da Universidade de Brasilia, sob orientação da Professora Doutora Eloisa Nascimento Silva Pilati.
\end{abstract}

Banca Examinadora:

Prof $^{\mathrm{a}}$. Dr ${ }^{\mathrm{a}}$. Eloisa Nascimento Silva Pilati (PPGL/UnB) - Presidente Prof ${ }^{\mathrm{a}}$. Dr ${ }^{\mathrm{a}}$. Marcia Niederauer (LIP/UnB) - Membro externo Profa. Dr ${ }^{\mathrm{a}}$. Heloisa Maria Moreira Lima Salles (PPGL/UnB) - Membro interno Prof ${ }^{\circ}$. Dr ${ }^{\circ}$. Marcus Vinicius S. Lunguinho (PPGL/UnB) - Suplente

Brasilia, 


\section{Agradecimentos}

A Deus por ter o controle de tudo, o que me faz ter certeza que, no fim, tudo terminará bem.

Aos meus pais, não há palavras que descrevam minha gratidão a todo sacrifício que fizeram para investir em mim. Obrigada por me amarem e me apoiarem em todas as minhas decisões.

Ao meu amado esposo, companheiro fiel que me ama, apoia e motiva sempre. Obrigada por me suportar durante essa árdua caminhada e ser um abrigo seguro na hora da tempestade.

Aos meus irmãos, escudeiros que, mesmo distantes, se fazem tão presentes com amizade sincera e constante amor.

Aos meus verdadeiros amigos que, junto com minha familia, multiplicam as alegrias e dividem as angústias das diversas etapas da vida, incluindo esta.

A minha querida orientadora, Profa ${ }^{\mathrm{a}}$ Dr ${ }^{\mathrm{a}}$. Eloisa Pilati, por acreditar em mim e pela paciência, compreensão e disponibilidade constantes, que me trouxeram à linha de chegada.

A todos esses, o meu mais profundo e sincero obrigada. 


\section{SUMÁRIO}

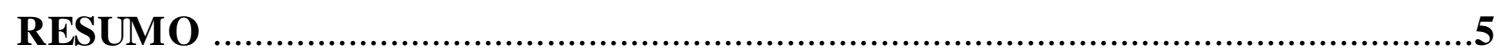

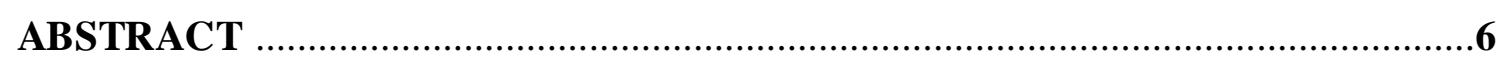

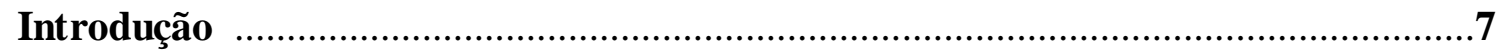

Capítulo 1. O gerativismo e a sala de aula: contribuições para a Educação Básica

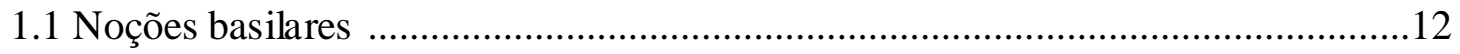

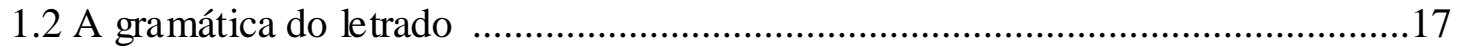

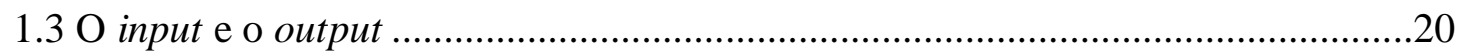

1.4 Sugestões metodológicas sob o olhar gerativista ..............................................24

1.4.1 Técnicas baseadas na gramática internalizada .........................................24

1.4.2 Os pressupostos gerativistas e os PCN's ................................................26

1.4.3 Formalismo e ensino de gramática na educação básica ............................28

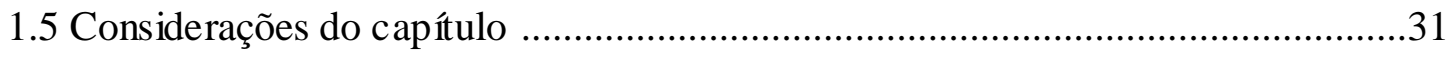

Capítulo 2. Aprendizagem ativa e "ensino" de gramática: repensando a

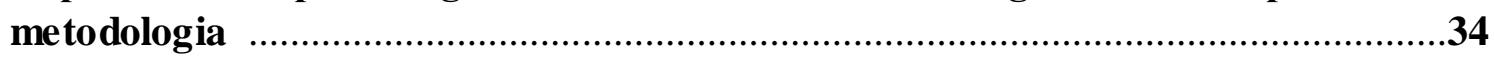

2.1 A importância da aprendizagem ativa .................................................................34

2.2 Estudo de caso sobre o desenvolvimento da consciência sintática em sala de aula 39

2.3 Práticas inovadoras para a sala de aula de gramática ........................................43

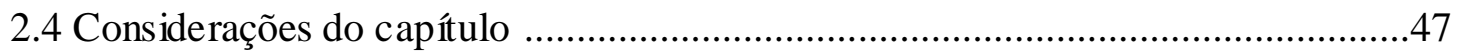

Capítulo 3. Projeto Piloto: aplicação de técnica e resultados .................................48

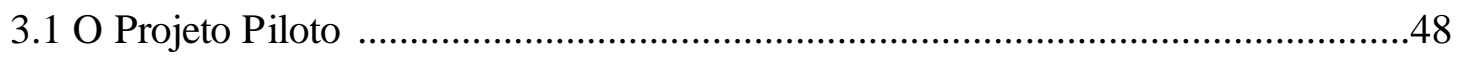

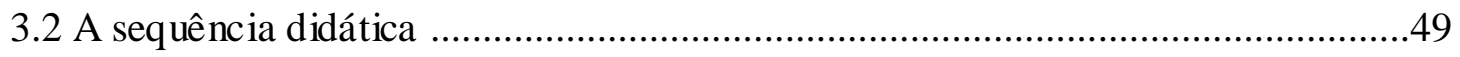

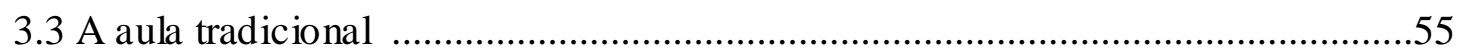

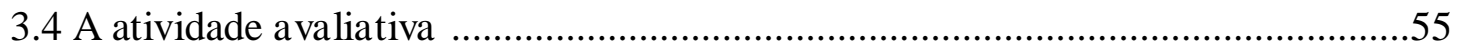

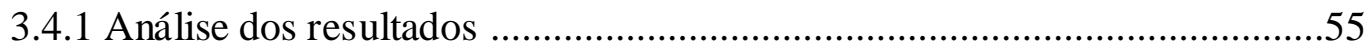

3.5 A avaliação da proposta pedagógica ..............................................................61

3.5.1 Análise dos resultados ......................................................................62

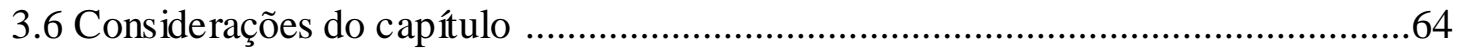

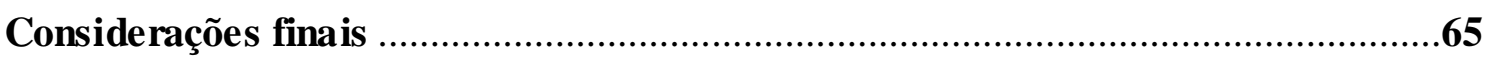


Referências bibliográficas .68

Anexo I .70

Anexo II . .79

Anexo III .84

Anexo IV . .88

Anexo V .90 


\section{RESUMO}

A presente pesquisa objetiva investigar, à luz dos pressupostos gerativistas e de uma metodologia de ensino baseada na aprendizagem ativa, os estudos e as propostas relativas à reflexão linguística, à revisão e à reescrita textual como formas de promover a consciência sintática nas aulas de gramáticas. O capítulo 1 trata da contribuição da teoria gerativa para o estudo de Língua Portuguesa a partir dos trabalhos de Chomsky (1965 e trabalhos posteriores), de Kato (2005) e de VanPatten (2003). Há, ainda, sugestões metodológicas baseadas nas pesquisas gerativistas de Lobato (2003), Pilati et al. (2011) e Vicente \& Pilati (2012). O segundo capítulo apresenta os estudos de Bransford et al. (2007) e Pilati (2014), que refletem sobre a aprendizagem e como ela se dá e discute trabalhos de Silva (2015) e de Pilati, Sandoval e Zandomênico (2016), que defendem a prática da revisão e da reescrita textual nas aulas de gramática. No terceiro capítulo há a elaboração, a aplicação e os resultados iniciais de um projeto piloto que propõe uma sequência didática baseada numa metodologia que usa o conhecimento prévio do aluno, a reflexão linguística e a aprendizagem com compreensão e trabalha com as atividades de revisão e reescrita textual. $\mathrm{O}$ projeto apresentou resultados satisfatórios e, se não unânimes, mostrou que situações de produções e análises de textos devem ser acrescentadas às aulas de gramática, pois a consciência linguística permite ao aluno entender seu sistema linguístico, levando-o a uma produção textual mais consciente que, alinhada ao senso crítico desenvolvido, produz autonomia.

Palavras-chave: teoria gerativa, ensino de gramática, consciência sintática, reflexão linguística, revisão e reescrita textual. 


\begin{abstract}
The present research aims to investigate, in the light of the generative assumptions and a methodology based on active learning, the studies and proposals related to linguistic reflection, revision and textual rewriting as ways to promote syntactic awareness in grammar classes. Chapter 1 deals with the contribution of generative theory to the study of Portuguese language, based on the works of Chomsky (1965 and later works), by Kato (2005) and VanPatten (2003). There are also methodological suggestions based on the generative research of Lobato (2003), Pilati et al. (2011) and Vicente \& Pilati (2012). The second chapter presents the studies of Bransford et al. (2007) and Pilati (2014), which reflect on learning and how it is given and discusses works by Silva (2015) and Pilati, Sandoval e Zandomênico (2016), who defend the practice of revision and textual rewriting in grammar classes. In the third chapter there are the elaboration, application and initial results of a pilot project that proposes a didactic sequence based on a methodology that uses the student's previous knowledge, the linguistic reflection and the learning with understanding and works with the activities of revision and textual rewriting. The project presented satisfactory results and, if not unanimous, showed that situations of production and analysis of texts should be added to grammar classes, because linguistic awareness allows the student to understand their linguistic system, leading to a more conscious textual production that, in line with the developed critical sense, produces autonomy.
\end{abstract}

Keywords: generative theory, grammar teaching, syntactic awareness, linguistic reflection, revision and textual rewriting. 


\section{Introdução}

A educação brasileira, de forma geral, vem enfrentando problemas relacionados a metodologias de ensino, valorização dos professores e ambiente escolar adequado. Um dos elementos que evidenciam os problemas enfrentados é o baixo crescimento do Índice de Desenvolvimento da Educação Básica (Ideb) ${ }^{1}$ em contrapartida ao aumento dos índices de evasão, que vem crescendo significativamente.

Segundo o Instituto Nacional de Estudos e Pesquisas Educacionais Anísio Teixeira (Inep) $)^{2}$, de 2007 a 2013, o Ideb subiu de 3.8 para 4.2 pontos nos anos finais do Ensino Fundamental e de 3.5 para 3.7 pontos, em referência ao mesmo período, no Ensino Médio. Apesar de o objetivo proposto pelo Ministério da Educação ser o de alcançar 6 pontos até 2022, o que corresponderia à média do sistema educacional dos países desenvolvidos, vê-se que o crescimento dos índices tem ocorrido de forma bastante lenta, principalmente no Ensino Médio.

Quanto à evasão escolar, o Relatório de Desenvolvimento $2012^{3}$, divulgado em 2013, do Programa das Nações Unidas para o Desenvolvimento (Pnud) ${ }^{4}$, constatou que, no Brasil, um a cada quatro alunos que inicia o Ensino Fundamental abandona a escola antes de completar a última série, o que equivale a uma taxa de 24,3\%, a terceira maior entre os 100 países com maior IDH (Índice de Desenvolvimento Humano).

Uma série de fatores justifica esses índices, como o sucateamento das escolas, desvalorização dos professores quanto a salários e investimentos na carreira, falta de material escolar, etc.. Entre eles está também a escolarização formal baseada em metodologias tradicionais, que gera o sentimento de que os conhecimentos de sala de aula não são úteis na vida prática.

\footnotetext{
${ }^{1}$ Índice criado em 2007 pelo Inep para medir a qualidade do aprendizado nacional e estabelecer metas para a melhoria do ensino. É calculado a partir de dois componentes: a taxa de rendimento escolar (aprovação) e as médias de desempenho nos exames aplicados pelo Inep. Os índices de aprovação são obtidos a partir do Censo Escolar, realizado anualmente, e as médias de desempenho são as da Prova Brasil, para escolas e municípios, e do Sistema de Avaliação da Educação Básica (Saeb), para os estados e o País, realizados a cada dois anos.

${ }^{2}$ Disponível em: <http://portal.inep.gov.br/web/portal-ideb/o-que-e-o-ideb> e

$<$ http://ideb.inep.gov.br/resultado/resultado/resultadoBrasil.seam?cid=12947522>

${ }^{3}$ Disponível em: <http://educacao.uol.com.br/noticias/2013/03/14/brasil-tem-3-maior-taxa-de-evasaoescolar-entre-100-paises-diz-pnud.htm>.

${ }^{4}$ Programa que executa diversos projetos em diferentes áreas com o objetivo de contribuir para o desenvolvimento humano, o combate à pobreza e o crescimento do país nas áreas prioritárias. Oferece aos parceiros apoio técnico, operacional e gerencial, por meio de acesso a metodologias, conhecimentos, consultoria especializada e ampla rede de cooperação técnica internacional. O Brasil é um dos países apoiados.
} 
As aulas de gramática, infelizmente, não fogem à regra. Grande parte das escolas adota um "ensino" "tradicional da gramática da Língua Portuguesa, doravante LP. Essa decisão tem sido tema constante de discussões e críticas de professores e linguistas, pois a gramática tradicional, que tem caráter prescritivo, prega um conjunto de regras "do bem falar e do bem escrever" levando em consideração uma única variedade da língua, a considerada "padrão" ou "culta", que guiará os julgamentos de "certo" ou "errado" na língua. Além disso, a técnica comum usada nesse sistema é a da memorização, que faz o aluno pensar que a gramática é um conjunto de regras arbitrárias, tornando a aula uma prática de decorar.

Neves (1994) investigou como as aulas de gramática vinham sendo ministradas no estado de São Paulo. A autora chegou à constatação de que as escolas

(a) dividem a LP em três disciplinas distintas: redação, leitura e interpretação e gramática, relacionando à atividade de produção textual, à cognitiva e à de análise a cada subdivisão, respectivamente;

(b) utilizam uma metodologia expositiva do conteúdo do livro didático;

(c) propõem atividades com predominância do exercício da "análise sintática" que giram em torno de um pequeno grupo de assunto;

(d) apresentam uma ordem padrão na ministração das aulas, consistindo, primeiramente, na explicação do conteúdo e, em seguida, na aplicação prática por meio de exercícios de repetição;

(e) transmitem conceituação por meio de definição, na grande maioria dos casos.

Mesmo sendo antiga, a pesquisa atesta aspectos interessantes das práticas docentes e conclui que o "ensino" de gramática está relacionado a um único procedimento didático: exposição de conceitos e resolução de exercícios.

Para a autora, um dos problemas está na compreensão do professor do que seja o conceito de gramática, que leva a negligência das atividades de reflexão e operação da linguagem, como especifica Neves (1994, p.41-42):

Exatamente porque os professores têm um conceito de gramática como: 1) atividade normativa, e/ou 2) atividade descritiva, toda a programação escolar reflete, na sua compartimentação, o desprezo pela atividade essencial de reflexão e operação sobre a linguagem. Contemplam-se, na verdade, ou as atividades de operação com a linguagem (redação, leitura, interpretação) ou as atividades de sistematização gramatical. Não se observa qualquer reserva de espaço para a reflexão sobre os procedimentos em uso, sobre o modo de relacionamento das unidades da língua etc.

\footnotetext{
${ }^{5}$ As aspas são usadas pelo entendimento que o aluno já chega à escola com o conhecimento inconsciente do funcionamento (regras) da sua língua. Esse conceito será discutido adiante.
} 
Tudo se passa como se o aluno estivesse na sala de aula para uma de duas atividades totalmente apartadas: 1) exercitar a linguagem estruturando/representando, comunicando experiências ou, no outro polo, interpretando experiências comunicativas (redação e leitura com interpretação) e 2) tomar conhecimento do quadro de entidades da língua [...] e tomar conhecimento do que se considera bom uso da língua (gramática).

Como resultado do avanço das pesquisas linguísticas no Brasil, alguns progressos já foram alcançados. Após os Parâmetros Curriculares Nacionais (PCNs), por exemplo, houve uma orientação para estudos relacionados ao texto, bem como a inclusão de temas relacionados à sociolinguística na Educação Básica. Os PCNs orientam os professores de LP a mudarem suas metodologias de ensino, o que já é um ganho para a área.

Nos últimos dez anos, a quase-totalidade das redes de educação pública desenvolveu, sob a forma de reorientação curricular ou de projetos de formação de professores em serviço (em geral os dois), um grande esforço de revisão das práticas tradicionais de alfabetização inicial e de ensino da Língua Portuguesa. [...]. O conhecimento atualmente disponível recomenda uma revisão dessa metodologia e aponta para a necessidade de repensar sobre teorias e práticas tão difundidas e estabelecidas, que, para a maioria dos professores, tendem a parecer as únicas possíveis (PCNs, 1997a, p.22).

Também na tentativa de contribuir para a renovação do "ensino" de gramática, vários estudos gerativistas também têm sido apresentados. Apesar das diversas pesquisas, como as de Lobato (2003), Pilati et al. (2011), Vicente \& Pilati (2012) e Pilati (2014), há pouco material disponível para que o professor utilize em sala de aula, conforme Silva (2013). As questões do "ensino" de LP, apesar de bastante discutidas, ainda não oferecem propostas metodológicas sistematizadas para que realmente haja mudança nas práticas docentes. Ao que parece, as abordagens acerca do conceito de linguagem ainda não estão bem sistematizadas, assim como as questões referentes à metodologia e à prática de ensino.

A ciência cognitiva, de igual modo, tem colaborado com estudos para renovar a educação. Essa nova ciência da aprendizagem visa aproximar pesquisa e sala de aula com o desenvolvimento de abordagens e técnicas.

Trinta anos atrás, os educadores prestavam pouca atenção ao trabalho dos cientistas cognitivos, e os pesquisadores do nascente campo da ciência cognitiva trabalhavam bastante afastados das salas de aulas. Atualmente, os pesquisadores cognitivos estão dedicando mais tempo ao trabalho com professores, testando e refinando suas teorias em salas de aulas reais, onde podem ver como os diversos ambientes e as interações nas salas de aula influenciam as aplicações de suas teorias (BRANSFORD et al., 2007, p.19). 
Pilati (2014) defende que os princípios gerais da ciência cognitiva ${ }^{6}$ sejam adotados em sala de aula e sugere que as atividades de revisão e reescrita textual podem ser eficazes nas aulas de gramática. Tais atividades seriam uma possível opção de ligação entre prática e teoria. A revisão e a reescrita textuais também são sugeridas pelos PCNs para as aulas de LP:

[...] são apresentados alguns princípios e orientações para o trabalho didático com os conteúdos, visando o alcance dos objetivos propostos para a área se o objetivo é que os alunos tenham uma atitude crítica em relação à sua própria produção de textos, o conteúdo a ser ensinado deverá ser procedimentos de revisão dos textos que produzem (PCNs, 1997a, p32).

Apesar da contribuição dos PCNs, dos trabalhos gerativistas e da ciência cognitiva, a grande maioria das escolas ainda divide a disciplina de LP em três blocos, quais sejam: (1) redação; (2) leitura e interpretação; e (3) gramática tradicional (NEVES, 1994). É consenso que a revisão e a reescrita textual são importantes nas aulas de redação, uma vez que todo o foco se dá em cima da produção de textos. O questionamento da presente pesquisa é se essa prática pode ser útil nas aulas de gramática.

A importância da revisão e reescrita textual é destaca por Brandão (2007, p.120121), numa obra dedicada ao "ensino" de gramática:

Revisar um texto é torná-lo objeto de nossa reflexão, é pensar sobre o que foi ou está sendo escrito e encontrar meios para melhor dizer o que se quer dizer, reelaborando e reescrevendo o já escrito. [...] Refletindo se seu escrito atende as suas intenções, bem como se está adequado à situação comunicativa em que ele se insere. [...] Ao revisar um texto, exige-se que o autor, continuamente, reflita sobre as "partes" efetivamente escritas e as avalie com base nos planos e objetivos traçados, em função do(s) destinatário(s) e finalidade previsto(s) para o seu texto, assim como do contexto comunicativo em que o texto está colocado. Trata-se, portanto, de uma habilidade metacognitiva complexa, que implica tornar-se consciente e pensar, deliberadamente, sobre processos e decisões tomadas durante a escrita de um texto.

Diante de todo esse cenário, a presente pesquisa deseja investigar, à luz dos pressupostos gerativistas, os estudos e as propostas relativas à reflexão linguística, revisão e reescrita textual como formas de promover a consciência sintática nas aulas de gramática, buscando contribuir com uma reflexão sobre uma possível saída do estudo de gramática meramente classificatório.

Considerando o exposto até aqui, têm-se como objetivos específicos:

\footnotetext{
${ }^{6}$ Os princípios da ciência cognitiva serão tratados mais a frente.
} 
a) Reunir, organizar e analisar os trabalhos prévios sobre educação linguística que envolvam a reflexão e a revisão e reescrita textual sob a ótica gerativista;

b) Fazer um projeto piloto que proponha uma sequência didática baseada nas orientações contidas nos estudos prévios expostos;

c) Analisar a eficácia de uma sequência didática baseada na aprendizagem ativa.

Esta dissertação, portanto, se justifica como uma tentativa de sistematizar uma prática pedagógica para amenizar a lacuna existente entre os estudos teóricos sobre linguagem e a carência de material didático disponível que oriente a prática pedagógica.

Para alcançar os objetivos propostos, o presente trabalho se divide em três capítulos. O primeiro expõe alguns pressupostos da teoria gerativa, baseado em Chomsky (1965 e trabalhos posteriores), além de trabalhos relacionados à teoria, como o de Kato (2005) e o de VanPatten (2003). Há, ainda, as pesquisas gerativistas de Lobato (2003), Pilati et al. (2011) e Vicente \& Pilati (2012), que abordam a teoria e o ensino linguístico. A finalidade do capítulo é refletir sobre a contribuição da teoria gerativa para o estudo de LP e, especificamente, de gramática em sala de aula.

O segundo capítulo apresenta os estudos de Bransford et al. (2007) e Pilati (2014), que refletem sobre a aprendizagem e como ela se dá. E discute trabalhos que defendem a prática da revisão e da reescrita textual para promover a consciência sintática nas aulas de gramática, como os de Silva (2015) e Pilati, Sandoval e Sandomênico (2016).

O terceiro capítulo mostra a elaboração, a aplicação e os resultados iniciais de um projeto piloto que tem como base a utilização da reflexão linguística, da revisão e da reescrita textual. E, por fim, as considerações finais fecham a dissertação com um balanço geral de todo o percurso do trabalho e as conclusões a que se chegou. 


\section{Capítulo 1}

\section{O gerativismo e a sala de aula: contribuições para a Educação Básica}

Este capítulo se propõe a discutir alguns princípios do gerativismo e suas contribuições para o estudo de LP, especificamente, de gramática em sala de aula. A primeira seção apresenta noções basilares da Teoria Gerativa se atendo aos conceitos fundamentais da Teoria de Princípios e Parâmetros, que permanecem pertinentes e trazem luz a um novo pensar sobre o "ensino" de língua materna. Como principal referência estão as pesquisas de Chomsky (1965 e trabalhos posteriores).

A segunda seção expõe a teoria de Kato (2005) sobre a gramática do letrado como uma questão de aquisição ou aprendizado e a forma como ela se dá, mostrando uma discussão teórica sobre a influência da escolarização no aprendizado linguístico.

Na seção seguinte, temos o trabalho de VanPatten (2003), que discorre sobre o input e o output com o propósito de responder como os aprendizes criam um sistema linguístico que subjaz o uso linguístico.

Após todos os conceitos e pressupostos expostos, a seção 1.4 apresenta trabalhos com sugestões metodológicas sob o olhar gerativista como forma de orientar o professor em sua prática de ensino tendo como base os trabalhos de Lobato (2003), Pilati et al. (2011) e Vicente \& Pilati (2012).

A seção 1.5 traz as considerações do capítulo com um panorama e a conclusão de toda a discussão até o momento.

\subsection{Noções basilares}

A Linguística Gerativa é uma corrente de estudos da ciência da linguagem cuja proposta teórica trata do desenvolvimento de línguas numa linha que relaciona a marcação genética à linguagem. Também chamada de gerativismo ou gramática gerativa ou, ainda, teoria gerativa, tem como objetivo elaborar um modelo teórico formal capaz de descrever e explicar abstratamente o que é e como funciona a linguagem humana. Surgiu no final da década de 50, nos Estados Unidos, com os trabalhos de Noam Chomsky. O marco inicial da teoria foi a publicação do livro Syntact 
Structures (Estruturas Sintáticas) em 1957. A teoria foi considerada por muitos como uma "revolução cognitiva", uma vez que sua noção de gramática provocou uma "mudança de perspectiva: do estudo do comportamento e seus produtos para os mecanismos internos usados pelo pensamento e pela ação humanos" (CHOMSKY, 1998, p.21). Nesse contexto, a análise do sistema linguístico, no gerativismo, é feita com base na cognição ${ }^{7}$ do falante.

Segundo Silva (2013), a teoria gerativa nunca se propôs a ser uma teoria de ensino, entretanto os resultados das pesquisas sobre linguagem e mente fomentaram as discussões sobre o ensino de línguas, à medida que defendem uma gama de conceitos que refutam o entendimento tradicional de "ensino" gramatical aderido pela maioria das escolas.

Seguem, abaixo, as noções basilares da Teoria Gerativa a partir dos conceitos fundamentais da Teoria de Princípios e Parâmetros, que permanecem pertinentes e trazem luz a um novo pensar sobre o "ensino" de língua materna.

A partir da constatação de que apenas os seres humanos falam, que é um instinto natural, Chomsky (1965) defende a hipótese da Faculdade de Linguagem. Para ele, à parte exceções, como casos de distúrbios neurológicos, todos os seres humanos têm uma predisposição genética a falar uma língua natural de forma inata, têm uma Faculdade de Linguagem, um aparato genético alocado no cérebro/mente que marca a diferença fundamental entre a espécie humana e todos os outros seres do planeta. Segundo o linguista, não existe um órgão único responsável pela linguagem, mas uma interligação entre vários setores da mente para que ela se efetue, o que constitui o pressuposto da modularidade.

A Gramática Universal (doravante GU) é um conjunto de propriedades e condições que constitui a base sobre a qual a língua se desenvolve. De acordo com Chomsky (1981), a mente humana, dada a Faculdade da Linguagem, possui uma matriz biológica que fornece a estrutura para o crescimento da linguagem, essa matriz seria a GU.

A Teoria de Princípios e Parâmetros defende que a GU é composta por princípios - leis gerais, fixas e universais, comuns a todas as línguas - e parâmetros não

\footnotetext{
${ }^{7}$ Ramo da psicologia que, nesse trabalho, se refere aos estudos dos processos de aprendizagem e de aquisição de conhecimento. "A perspectiva cognitiva vê o comportamento e seus produtos não como o objeto de investigação, mas como dados que podem oferecer evidências sobre os mecanismos internos da mente e os modos como esses mecanismos operam ao executar ações e interpretar experiências." (CHOMSKY, 1998, p.21)
} 
fixados - um leque de opções disponíveis dentro da GU que são as propriedades específicas de cada língua e que constitui a distinção entre elas. A criança fixa os parâmetros à medida que entra em contato com um sistema linguístico, um input. A fixação dos parâmetros constitui a língua materna, a gramática internalizada, a línguaI.

A mediação entre o estado inicial da Faculdade da Linguagem e os estados que ela pode alcançar é chamado de Aquisição da Linguagem. Esse dispositivo permite um mapeamento mental das estruturas linguísticas de uma língua a partir da exposição linguística, do contato com o input. Desta forma, o input é a base para a aquisição de uma língua e se constitui dentro de um contexto comunicativo

Cada língua é o resultado da atuação recíproca de dois fatores: o estado inicial e o curso da experiência. Podemos imaginar o estado inicial como um "dispositivo de aquisição de língua" que toma a experiência como um "dado de entrada" (input) e fornece a língua como um "dado de saída" (output) que é internamente representado na mente/cérebro (CHOMSKY, 1998, p. 19).

Nesse processo, as crianças são expostas a estruturas linguísticas de toda natureza: fragmentos, inícios interrompidos, truncamentos e outras estruturas típicas da fala (CHOMSKY et al., 1970). Além disso, é impossível elas terem contato com todos os dados disponíveis da língua, cada criança recebe um estímulo distinto a depender do ambiente linguístico a que é exposta. Ainda assim, elas conseguem dominar, sem esforço, um sistema complexo e sofisticado como é uma língua natural. Antes mesmo de chegarem à escola, elas são capazes de compreender e produzir uma língua. Chomsky (2006) defende que isso ocorre porque a GU usa todos os estímulos disponíveis, por mais pobres ${ }^{8}$ que sejam, para organizar o sistema linguístico na mente. Apesar de estímulos pobres, a alta capacidade cognitiva do ser humano (Faculdade da Linguagem) permite a aquisição da língua. Tal conceito é chamado de Argumento da Pobreza de Estímulo.

Voltando aos princípios e parâmetros, uma sentença que viola um princípio não é tolerada, diz-se que é agramatical. Já uma sentença que não atende a uma propriedade paramétrica pode ser permitida em uma língua, ser gramatical, mas não em outra. Essas noções de gramaticalidade só podem ser dadas pelo falante nativo, uma vez que ele possui, mesmo de forma inconsciente, o conjunto das regras gramaticais da sua língua internalizadas. A esse conhecimento linguístico inconsciente, essa capacidade natural e

\footnotetext{
${ }^{8}$ A expressão "estímulo pobre" é usada no sentido de "desorganizado", as crianças estão expostas a estímulos desorganizados.
} 
inconsciente de acessar a gramática da língua materna (língua-I) para produzir e entender sentenças e ter intuições sobre a língua dá-se o nome de competência linguística, que é uma noção abstrata, pois compreende todo o repertório possível de uma língua. A contraparte concreta da competência é chamada de desempenho ou performance, que é a produção de sentenças, o uso desse conhecimento internalizado pelo falante para exteriorizar a língua (língua-E). A Teoria Gerativa tem como objeto de estudo a competência, já que, uma vez que se propõe a descrever e explicar os mecanismos gramaticais da língua, precisa ser capaz de lidar com sentenças que ainda não foram produzidas e com sequências de palavras que nunca serão. Nesse contexto, só a competência abarca todas as possibilidades e impossibilidades da língua.

Outro conceito importante exposto por Chomsky (2006) e que está diretamente ligado à competência é a criatividade, que consiste na liberdade que o falante tem de criar enunciados nunca utilizados e na capacidade de decodificar enunciados com os quais não teve contato. Claro que é uma criatividade regida pelos princípios gerais das línguas e os parâmetros de sua língua específica, ou seja, pelas possibilidades que a língua oferece. É exatamente aí que a criatividade se aproxima da competência pela necessidade de acessar o conhecimento gramatical da língua. A criatividade também diferencia os seres humanos, dado que, a partir dela, somos capazes de combinar um número finito de itens gerando um número infinito de sentenças.

Assim, segundo Chomsky (1981), podemos resumir o desenvolvimento do conhecimento de uma língua como consequência da "interação de princípios geneticamente determinados e de um determinado curso de experiências" (CHOMSKY, 1981, p.103). Informalmente, Chomsky (1981) chama este processo de "aprendizagem linguística", mas alerta que, "na verdade não aprendemos ${ }^{9}$ uma língua; o que ocorre é que a gramática se desenvolve (cresce) na mente” (CHOMSKY, 1981, p.103).

Enfim, a gramática gerativa procura constituir um modelo teórico capaz de descrever e explicar a natureza e o funcionamento da Faculdade da Linguagem, isto é, busca compreender um dos aspectos mais importantes da mente humana, conforme Chomsky (1980, p.09):

Uma das razões para estudar a linguagem (exatamente a razão gerativista) - e para mim, pessoalmente, a mais premente delas - é a possibilidade instigante de ver a linguagem como um "espelho do espírito", como diz a expressão tradicional. Com isto não quero apenas dizer que os conceitos expressados e as distinções desenvolvidas no uso normal da linguagem nos revelam os modelos do pensamento e o universo do "senso comum" construídos pela

\footnotetext{
${ }^{9}$ A gramática interna é adquirida pela Faculdade de Linguagem acrescida do input fornecido.
} 
mente humana. Mais instigante ainda, pelo menos para mim, é a possibilidade de descobrir, através do estudo da linguagem, princípios abstratos que governam sua estrutura e uso, princípios que são universais por necessidade biológica e não por simples acidente histórico, e que decorrem de características mentais da espécie humana.

A gramática gerativa tem a ver, então, com o conhecimento inconsciente ("características mentais") que o falante da língua possui, sua capacidade de desenvolver uma língua materna, independentemente do nível de experiência linguística a que é submetido e, antes mesmo, de ter frequentado a escola.

O conhecimento dos conceitos acima expostos, que são as bases da teoria gerativa, é importante para os professores de língua materna por oferecer subsídios teóricos indispensáveis para o entendimento da natureza do conhecimento linguístico dos indivíduos que frequentam a escola (SILVA, 2013).

O conceito de Inatismo $^{10}$ permite um novo olhar do professor em relação ao aluno que passa a ser visto como alguém que já possui conhecimento linguístico vasto sobre o sistema linguístico da fala, mesmo que de forma inconsciente. Ao ensino, portanto, não caberia "ensinar" a língua, mas trazer à consciência o conhecimento já possuído, tornando o aluno apto a manipular de maneira reflexiva a estrutura de seu idioma.

A hipótese da Aquisição de Linguagem reafirma a postura anterior, pois permite entender de que maneira o aluno inicia os conhecimentos de sua língua materna, revelando que não aprendemos uma língua, mas que a gramática de nossa língua materna é desenvolvida na nossa mente inconscientemente a partir da fixação dos parâmetros da língua com que temos contato. Essa noção facilita o trabalho do professor ao oferecer subsídios para que ele perceba as estruturas linguísticas que já foram adquiridas pelos alunos e as que eles ainda aprenderão.

A junção da hipótese da Gramática Universal, que tem a ver com a capacidade mental dos indivíduos para a aquisição de sistemas linguísticos, com a hipótese do Input, que responde aos questionamentos sobre o que é preciso se ter para que haja aquisição, origina a explicação desse conhecimento inconsciente já adquirido como fruto do contato linguístico, e não do ensino formal. Isto posto, o professor não pode partir do pressuposto que o aluno é desprovido de conhecimento, mas deve se atentar para o fato de o aluno ser competente em sua língua.

\footnotetext{
${ }^{10}$ Capacidade inata que o ser humano tem de adquirir uma língua, é a Faculdade de Linguagem.
} 
A hipótese do Argumento da Pobreza de Estímulo está intimamente relacionada à do Input, que mostra que a aquisição acontece a despeito do input oferecido ser estruturado ou não. Entretanto, a consciência de que a sala de aula é um lugar, talvez o único a depender da realidade do aluno, onde o discente tem a oportunidade de desenvolver a consciência sintática, permitindo-lhe tomar consciência das estruturas da língua e manipulá-las, torna imprescindível uma seleção e uma organização apurada do input. Assim, o trabalho do professor estaria relacionado ao Desempenho e essa gama de informações permite-lhe delimitar bem seus objetivos para proporcionar estímulos direcionados à aquisição da gramática da escrita.

Percebemos, portanto, que os conceitos gerativistas se complementam e permitem um novo pensar sobre o ensino, possibilitando uma reestruturação do trabalho em sala de aula a partir da compreensão da natureza da linguagem.

\subsection{A gramática do letrado}

Kato (2005) afirma que, no Brasil, a gramática da fala e a "gramática" da escrita apresentam uma distância tal que a aquisição da escrita pode se equiparar à aprendizagem de uma segunda língua (L2). A autora, então, se propõe a refletir sobre a aquisição/aprendizagem da escrita questionando a natureza do conhecimento linguístico do letrado brasileiro e como ele atinge esse conhecimento.

Sobre a aquisição da linguagem, da gramática da fala, a autora usa o conceito de periferia marcada para dar conta da aprendizagem de uma segunda "gramática", a partir do input ordenado escolar ou da imersão em textos escritos. Dito de outro modo, temos uma gramática nuclear quando todos os valores dos Parâmetros estão selecionados, entretanto, não é só essa gramática nuclear que constitui a Língua-I, há ainda uma periferia marcada, que, segundo Chomsky (1981), "pode abrigar fenômenos de empréstimos, resíduos de mudança, invenções, de forma que indivíduos da mesma comunidade podem ou não apresentar esses fenômenos de forma marginal" (KATO, 2005, p.2).

Kato (2005) considera três hipóteses para a natureza do conhecimento linguístico do letrado brasileiro: (1) o processo de letramento recupera o conhecimento gramatical de um indivíduo de alguma época passada do português brasileiro; (2) esse conhecimento privilegia a unidade linguística, é pautado no conhecimento linguístico do 
falante; e (3) esse saber é definido como algo distinto das hipóteses anteriores. Ela defende a terceira hipótese.

Quanto ao conhecimento da gramática da escrita, Kato (2005) afirma que, no português brasileiro, há semelhanças entre aquisição da escrita e aprendizagem de L2, são elas: (a) os dois processos são socialmente motivadas e não biologicamente determinadas; (b) nos dois casos, o início da aprendizagem começa, em geral, depois da idade crítica para a aquisição; (c) o processo, nos dois casos é, essencialmente consciente; (d) acredita-se, nos dois casos, que o sucesso depende de dados positivos e negativos, ou seja, da qualidade do input recebido; (e) em geral, o processo nas duas "aquisições" é vagaroso e não instantâneo; e (f) nos dois casos, há mais diferenças individuais (cf. KATO, 2005, p. 6).

Segundo a autora, as teorias de aquisição da gramática de L2 levantam duas hipóteses: (1) a do não acesso à GU, em que a aprendizagem se daria através de um mecanismo multifuncional, distinguindo, assim, "aquisição", para L1, de “aprendizagem", para L2, e (2) a que propõe o acesso indireto à GU através da L1 já adquirida plenamente. O desenvolvimento do conhecimento da escrita, por sua vez, segue a mesma linha e também apresenta a hipótese de nenhum acesso à GU e a hipótese de acesso indireto à GU, através da gramática da fala. A autora defende o acesso indireto à GU, via a primeira gramática (L1), no caso, a gramática da língua falada.

Partindo do trabalho de Hershensohn (2000), que defende o acesso à GU na aquisição de L2, Kato (2005) usa argumentos similares para defender a tese sobre o acesso à GU na escrita, considerando que esta "a) é restrita pelos mesmos Princípios da GU; b) faz uso das mesmas categorias e funções (podem ser descritas pela mesma metalinguagem); e c) as opções gramáticas nelas presentes são previstas pelos Parâmetros da GU” (KATO, 2005, p.7).

Admitindo que tanto a gramática da L2 quanto a "gramática" da escrita (a "segunda gramática" - G2), se dá via acesso à GU, a autora questiona sobre como ocorre esse acesso. A linguista levanta duas hipóteses sobre o estatuto da "gramática" da escrita na mente do falante. Para ela, a aquisição de uma "segunda gramática" se dá (1) pelo falante letrado ter duas gramáticas nucleares - G1 e G2 com o mesmo estatuto, como gramáticas distintas; ou (2) pelo falante letrado ser um bilíngue desigual que alterna entre a G1 da gramática nuclear e a G2 na periferia marcada e tem, em sua 
Língua-I, uma periferia marcada maior do que a dos não letrados. Contudo, a autora apresenta uma ressalva sobre a G2 da "gramática" da escrita:

Essa G2, na minha concepção, não tem a mesma natureza da G1, sendo constituída de fragmentos superficiais de uma gramática constituída pela fixação de parâmetros. [...] O que parece ocorrer, efetivamente, é que a "G2" é constituída, não por seleção paramétrica, mas por "regras estilísticas", selecionadas arbitrariamente de gramáticas passadas ou emprestadas da gramática portuguesa (KATO, 2005, p.9).

A autora conclui, a partir da natureza das regularidades e arbitrariedades observadas na aprendizagem da escrita, apesar das semelhanças entre esta e a aquisição de L2, que a hipótese (1) responde mais pelo conhecimento resultante de L2, e a hipótese (2) espelha melhor o tipo de conhecimento do letrado.

Kato (2005) conclui seu artigo afirmando que:

As gramáticas nucleares ficam restritas ao conhecimento acessível a qualquer ser humano, enquanto tudo o que nos diferencia se encontra nessa periferia que expande nossa Língua-I. Embora o que constitui a "G2" tenha a natureza de "regras estilísticas", o fato de elas serem selecionadas de um acervo de construções originárias da GU, seja da gramática do falante do século XIX, seja do falante português, faz delas um subproduto da nossa GU (KATO, 2005, p.9).

Assim, apesar de a autora entender a "gramática" da escrita como um subproduto da GU, sendo aprendida por acesso indireto a ela, podemos concluir, que, por ser constituída de regras estilísticas armazenadas e utilizadas de maneira arbitrária, e não por seleção paramétrica, ela não pode ser considerada uma gramática nuclear. Pelo acesso indireto à GU, podemos considerá-la, então, uma periferia marcada.

Tal hipótese explicaria um tipo de bilinguismo que faz alternância de código entre a G1 da gramática nuclear (gramática da fala) e a "gramática" da escrita na periferia marcada. Deste modo, essa ideia representa um avanço para o entendimento das diferenças entre a fala e a escrita atualmente, entretanto é preciso considerar que, para Kato (2005), deve haver mais informações sobre a natureza dessa periferia marcada no sentido de delimitar melhor suas características, regularidades ou irregularidades, se houver.

Essa informação faz o professor refletir, pois, assumindo o pressuposto que o aluno, ao chegar à escola, já possui uma gramática internalizada, tem sua gramática nuclear definida, ou seja, já é competente em sua língua, não faz sentido ministrar aulas de gramática como se o discente não conhecesse o cerne do assunto, a língua. Uma vez entendido esse princípio, o professor pode partir do conhecimento prévio que o aluno tem para auxiliá-lo na reflexão sobre o que ele já sabe em termos de estrutura linguística 
na modalidade falada e usar esse conhecimento para introduzir e/ou aprimorar a modalidade escrita.

Outra questão que o pressuposto da gramática internalizada (nuclear) levanta é que, na escola, uma nova gramática (a gramática da escrita) será aprendida na periferia marcada, que será um subproduto da GU, portanto, torna-se compreensível que o aluno acesse sua gramática nuclear, a gramática da fala, enquanto as propriedades da periferia marcada não estiverem apropriadas. Uma situação que retrata esse fenômeno é quando, na escrita, os alunos apresentam estruturas próprias da fala. A compreensão de que o acesso à gramática nuclear é um recurso à falta de propriedades da periferia marcada é imprescindível para que o professor perceba as estruturas que precisam ser adquiridas e/ou aperfeiçoadas pelo aluno, e para que olhe para a produção do discente com mais cautela no que se refere à correção de trabalhos escritos que os alunos venham a apresentar com desvios típicos desse processo.

\subsection{O input e o output}

Os conceitos de input e output já foram apresentados anteriormente de acordo com os pressupostos gerativistas propostos por Chomsky. Entretanto, no que tange ao ensino e à aquisição de segunda língua, uma vez que a "gramática" da escrita, no Brasil, se assemelha a uma L2, vale a pena aprofundar essas noções a partir do trabalho de VanPatten (2003).

Para o autor, a aquisição de segunda língua é complexa e constituída pelos seguintes processos: (a) o processamento de entrada - input - que consiste no sentido que os aprendizes dão à linguagem que ouvem e lêem e como tiram um dado linguístico disso; (b) a acomodação, que tem relação com o modo como os aprendizes realmente incorporam uma forma gramatical ou estrutura dentro de uma imagem mental da língua que estão criando; (c) a reestruturação, que se baseia na mudança de formas e estruturas de maneira inconsciente a partir da incorporação de outras formas ou estruturas; e (d) o processamento de saída - output - que se refere à habilidade de fazer uso de um conhecimento implícito que os aprendizes estão adquirindo para produzir sentenças.

Para os pesquisadores em aquisição de segunda língua, a aquisição de L1 é tida como uma interseção dos mecanismos internos inatos das crianças e do input, os dados linguísticos a que são expostas a cada interação. A aquisição de L2, por sua vez, envolve a criação de um sistema linguístico implícito, inconsciente, ainda que haja 
conhecimento explícito. Desta forma, VanPatten (2003) afirma que a realização final em L2 não tem relação com instrução, uma vez que a aquisição de habilidades é diferente de criação de um sistema implícito. Assim como falantes nativos fazem, aprendizes de L2 armazenam as informações explícitas aprendidas separadamente do seu sistema implícito.

O autor acredita que aprendizes de L2, assim como os de L1, recebem input, pois, à medida que tentam compreender algum dado ou estrutura da L2, estão obtendo input que serve de base para a aquisição. Nesse processo, ele faz conexões entre o significado e como ele é codificado. Por isso, defende que a aquisição ocorre como um produto da compreensão. Entretanto, o autor ressalta que input para aquisição não é informação sobre a língua, não é aprender uma regra, e não é preenchimento de exercício para praticar formas verbais. Em contextos de sala de aula, input escrito pode servir como input linguístico também, mas as conexões entre leitura e o desenvolvimento de um sistema linguístico implícito precisam ainda ser exploradas detalhadamente. Enfim, para o autor, sem input não há aquisição e, apesar de poder desempenhar um papel de apoio, conhecimento explícito não é input. Input é o contato com o sistema linguístico de uma língua diretamente relacionado às exigências comunicativas nas diversas situações apresentadas.

VanPatten (2003) propõe que o sistema de desenvolvimento da linguagem do aprendiz possui três componentes fundamentais: uma rede de associações, um componente sintático que consiste em regras, e um conjunto de competências relacionadas ao uso da língua, à comunicação. A partir daí, tanto aprendizes de L1 quanto de L2 criam sistemas similares com uma variedade de componentes linguísticos conectados com base em um relacionamento semântico, lexical e formal, ou seja, as redes em L1 e L2 podem não ser iguais, mas são criadas baseadas nos mesmos processos de aprendizagem.

Por essas redes terem uma mesma base, mas serem diferentes, aprendizes de L2 precisam de muita exposição a diferentes contextos para aprender como a língua é usada enquanto aprendizes de L1 podem precisar que lhes digam que algo que disseram é inapropriado.

Para o autor, o processamento do input é o estágio inicial da acomodação. Formas e significados precisam ser, durante a compreensão, candidatos para acomodação dentro da rede. A frequência de sua aparição no input também ajuda a determinar quão rápidas as conexões podem ser feitas e quão fortes serão. 
A contrapartida do input é o output, que é a língua que um aprendiz produz para expressar algum tipo de significado. Para VanPatten (2003), ao menos dois processos estão envolvidos no processamento de output: acesso e produção de estratégias. O acesso é a ativação de itens lexicais e formas gramaticais necessárias para expressar significados particulares. Quanto à produção de estratégias, falantes de L1 têm apenas um conjunto, que é o da língua materna. Aprendizes de L2, por sua vez, podem acessar dois conjuntos distintos: o das estratégias de produção em L1 e o das estratégias apropriadas em L2. Por isso, quando eles precisam se comunicar além das estratégias já apropriadas em L2, recorrem às estratégias de produção da L1, o que gera um resultado com algo que soa como L2, mas tem a estrutura de L1, que é uma situação recorrente na formação do escolarizado.

Nesse contexto, o professor precisa ter o mesmo cuidado mencionado em Kato (2005) quanto à gramática nuclear e a periferia marcada porque, quando da aquisição da gramática da fala (L1), os alunos produzem livremente um output truncado, sem a fixação clara de parâmetros e, muitas vezes, ininteligíveis. Na aprendizagem da "gramática" da escrita, esse processo não é diferente, por isso, não faz sentido que a escola imponha que o aluno não cometa equívocos na escrita e o submeta a uma correção rígida a cada tentativa.

VanPatten (2003) afirma que as estratégias de produção baseadas na L2 se desenvolvem com o tempo até se automatizarem, até que o aprendiz produza output com pouco ou nenhum esforço, sem pensar sobre isso. Contrariando a crença de que, na criação do sistema linguístico do aprendiz, aprendem-se regras com a prática de output, o autor resume output como o resultado de um engajamento do aprendiz com o input, que tem um papel de negociar sentidos e encorajar outros processos que ajudam os aprendizes a adquirirem a língua.

Sobre a sala de aula, o autor acredita que o output de L1, a língua falada dos aprendizes, não conduz diretamente à aquisição do sistema implícito, ainda que contribua para o desenvolvimento de uma habilidade. Para ele, o output leva o aluno a ter consciência de que precisa de uma forma ou estrutura pelo monitoramento do output em L1 e em L2. Em L1, confia-se em um sistema inconsciente e implícito, já em L2, o monitoramento pode ser feito através do conhecimento explícito (consciente). Para monitorar, aprendizes precisam saber a regra. Portanto, a regra precisa existir, ou no sistema implícito, ou no conhecimento explícito, mas não é o ponto principal, pois não leva à aquisição, leva a um conhecimento explícito que pode ser aproveitado para 
propósitos comunicativos. O principal, nesse processo, é a prática entendida como prática em ideias comunicativas, isto é, falando sobre coisas reais.

Segundo o autor, aprendizes precisam de interação por todo o percurso, e habilidades de fala e procedimentos de output precisam ser adquiridos e desenvolvidos, já que a aquisição ocorre em algum tipo de contexto comunicativo, ressaltando que é preciso considerar as diferenças individuais no aprendizado. À vista disso, VanPatten (2003) insiste que não há um método certo, mas sim abordagens principais para a instrução linguística, entretanto, a comunicação deve ser o centro da aquisição linguística, uma vez que as pessoas adquirem uma língua por engajamento em comportamentos comunicativos. Portanto, a relação entre aquisição e ensino consiste em uma aquisição orientada, em que, quanto mais houver input e embasamento no significado, melhor, uma vez que geraria output mais coerente, eficaz e significativo para o crescimento cognitivo do aluno.

VanPatten (2003) afirma que o input pode ser incorporado no currículo de ensino de língua de várias formas que levem à aprendizagem por algum tipo de assunto importante ou outro conteúdo pela segunda língua, e não com foco na língua por ela mesma. Um currículo que incorpora o input tanto quanto possível é um currículo que encoraja a aquisição linguística, porque, quanto mais o currículo coloca a comunicação no centro das lições, tornando o significado central a despeito da forma sozinha, tanto mais este currículo perece prover um input ótimo.

A importância do input emerge novamente e, cabe ao professor, organizar esse contato com tarefas que prezem pela comunicação, seja com um input falado ou escrito, e pela compreensão, dado que o aluno precisa compreender o que e o porquê está tendo contato com o material da aula e, ainda, como lidar com os dados linguísticos nas situações de comunicação que se apresentam.

O autor também destaca o ensino com um input escrito e com situações de interação que se orientam por um esquema de apropriação de acordo com o nível de cada aluno (iniciante, intermediário e avançado). Segundo ele, as produções requeridas dos alunos não precisam ser necessariamente interativas, mas devem ser comunicativas em sua natureza, ou seja, podem ter foco na instrução gramatical, desde que sejam baseadas no significado e ligadas ao input e à comunicação.

O trabalho de VanPatten (2003) é interessante porque: (1) busca responder como os aprendizes criam um sistema linguístico que subjaz o uso linguístico considerando que toda produção tem um fundamento cognitivo e segue uma logicidade, esse fator, 
inclusive, é uma das relações que se estabelece entre a obra e o gerativismo; (2) traz contribuições sobre como a aquisição em sala de aula pode se dar de forma mais efetiva que as abordagens instrucionais vigentes, já que buscar entender o que acontece entre o input e o output é um caminho para se melhorarem as questões do ensino de língua; e (3) pode ser considerado uma avanço do trabalho de Kato (2005) ao defender a hipótese de criação de um sistema linguístico implícito para a aprendizagem da "gramática da escrita", tirando tal gramática da periferia marcada e levando-a à aquisição de fato, para a gramática nuclear. Isto possibilitaria que o conhecimento da gramática da escrita fosse natural e intuitivo como o da gramática da fala é.

Tal obra contribui em vários sentidos para o "ensino" de LP ao chamar atenção para: (1) a aquisição envolver a criação de um conhecimento implícito inconsciente, mesmo que se tenha tido um aprendizado de regras explícitas através da aprendizagem formal em sala de aula; (2) a seleção criteriosa do input por parte do professor ser fundamental; (3) o aluno acessar as estratégias de produção da L1 quando as estruturas adquiridas da L2 não dão conta da comunicação; e (4) a aquisição ocorrer em contexto comunicativo e ser um produto da compreensão, pois o aprendiz faz conexões entre o significado e como o significado está codificado. O item (4) ganha destaque, uma vez que o contexto comunicativo deve ser o centro da aquisição linguística, porquanto a prática comunicativa gera controle expressivo, por isso a aquisição deve ser orientada por input planejado e embasado no significado.

\subsection{Sugestões metodológicas sob o olhar gerativista}

Como resultado dos conceitos gerativistas e dos estudos decorrentes deles, algumas ideias metodológicas foram sugeridas. Dentre elas, destacam-se as propostas de Lobato (2003), de Pilati; Naves; Vicente \& Salles (2011) e de Vicente \& Pilati (2012).

As propostas não serão apresentadas em ordem cronológica para seguir uma complementação lógica dos trabalhos, Lobato (2003) é complementado por Vicente \& Pilati (2012) e Pilati et al. (2011).

\subsubsection{Técnicas baseadas na gramática intemalizada}

Lobato (2003) reflete sobre a necessidade de o professor da educação básica conhecer os estudos linguísticos. Seguindo os pressupostos gerativistas, a autora 
defende que, em sala de aula, deve-se trabalhar a gramática como algo interno, como um constructo mental que se apresenta de forma dinâmica, interna ao indivíduo e com propriedades explicativas do caráter criativo do uso das línguas naturais. Afinal, uma vez que o aluno já chega à escola com a gramática da sua língua internalizada, não há necessidade de trabalhá-la como algo externo a ele, como um conjunto de descrições.

A partir dessa concepção, Lobato defende uma sugestão metodológica de ensino que permitiria ao aluno verificar por si mesmo que "o ensino gramatical tem uma razão de ser, pois (o aluno) percebe que sentido obtém com tal ou qual estrutura" (LOBATO, 2003, p.6). Para ela, uma metodologia deve se pautar em:

(1) procedimentos de descoberta que objetivam levar o aluno à descoberta de novas informações com base na análise de estruturas de sua língua;

(2) metodologia de eliciação que busca direcionar o aluno a tirar conclusões a partir da análise dos dados, além de acelerar o procedimento de descoberta;

(3) técnica de resultados que consiste em trabalhar com estruturas dando ênfase ao fato de que cada estrutura corresponde a certo resultado semântico.

Uma consequência desse processo é o aluno melhorar seu domínio de textos, porque, conhecendo e entendendo a estrutura de sua língua, ele pode manipulá-la para alcançar o resultado semântico que deseja.

Para Lobato, o "ensino" de gramática é importante porque (1) subjaz ao texto e às atividades discursivas em geral a mesma gramática abstrata que subjaz às palavras, aos sintagmas, às orações e às frases; (2) o entendimento dos mecanismos gramaticais e de seus efeitos semânticos ajuda o aluno a ganhar tempo no seu processo de domínio das atividades discursivas em geral; e (3) o aluno chegará sozinho às conclusões a respeito do funcionamento do idioma, de que existe uma faculdade de linguagem, com o uso adequado do método proposto pela autora.

Apesar de a autora afirmar que o aluno, ao seguir esse método, chegará sozinho às conclusões a respeito do funcionamento do idioma e não deixar claro os limites da interferência do professor no desenvolvimento dos conhecimentos linguísticos do aluno, não se pode esquecer o papel ímpar que o professor desempenha como mediador do processo de ensino-aprendizagem. Isso se confirma pela ideia defendida tanto pela autora quanto pela teoria gerativa de que a modalidade escrita da língua não é inata como a modalidade oral, portanto, o papel do professor no direcionamento do processo de ensino-aprendizagem com instruções específicas para seu desenvolvimento se faz necessário. 
Por fim, Lobato acredita que a gramática não deve ser deixada de lado, o que é necessário é a mudança na forma como é ensinada. Para ela, a concepção de gramática como algo biológico precisa ser difundida para que os professores assimilem esse conceito e realizem certas transformações na educação, como (1) modificação do conteúdo programático, que deve ser feita paulatinamente no ensino básico, sendo urgente, entretanto, a necessidade de alterar a metodologia; (2) análises linguísticas que partam dos dados, com adoção do procedimento de descoberta, da metodologia de eliciação e da técnica dos resultados, seguindo os processos metodológicos propostos por ela.

\subsubsection{Os press upostos gerativistas e os PCN's}

Vicente \& Pilati (2012) se propõem a mostrar que o "ensino" de LP a partir dos pressupostos da gramática internalizada é possível sob a ótica dos PCN's, apresentando a relação de concordância dos pressupostos gerativistas com as diretrizes presentes nos Parâmetros Curriculares Nacionais (PCNs).

A influência da teoria gerativa pode ser observada em várias passagens do texto dos PCNs que abrem espaço para a aplicação de pressupostos básicos gerativistas, como "faculdade de linguagem", "competência", "criatividade", ainda que não mencionados de forma explícita. Vê-se de maneira recorrente que os PCNs valorizam o "conhecimento prévio" para focalizar o modo que o aluno aprende, e não a forma que se ensina. Contudo, as autoras chamam a atenção que o conceito de "conhecimento prévio" destacado nos PCNs não é o mesmo com o qual a teoria gerativa trabalha.

Para a gramática gerativa, "conhecimento prévio" se refere ao conhecimento linguístico inato aos seres humanos (competência linguística) que permite ao falante ter a gramática da sua língua internalizada antes mesmo de frequentar o ensino formal. Nos PCN's, o termo parece corresponder a conteúdos previamente aprendidos na escola e que vão sendo revistos e aprofundados ao longo dos anos. Por conta dessa distinção de conceitos, as autoras defendem que os PCNs devem reformular tal noção para que o processo de ensino-aprendizagem ocorra de maneira mais eficiente, já que elas acreditam que o conhecimento prévio do aluno não está relacionado somente ao conteúdo que já visto em séries anteriores na escola, mas a todo arcabouço linguístico que ele carrega desde a aquisição de sua língua materna. 
Para Vicente \& Pilati (2012), a atuação de linguistas foi crucial para a elaboração dos PCNs, apesar de não apresentarem formas práticas para que os objetivos ali propostos sejam alcançados. Isso é compreensível à medida que esse documento objetiva oferecer parâmetros para o ensino, por isso, não se vêem exemplos práticos de como o professor poderia desenvolver e sistematizar o conhecimento prévio do aluno, ou de como incentivar o domínio de outras variedades linguísticas.

As autoras defendem que a função da escola é (1) alfabetizar o aluno mostrando a relação entre os sons e as letras; (2) promover o letramento apresentando os valores sociais de diferentes textos e gêneros; e (3) desenvolver a capacidade de expressão escrita e oral do aluno, dentro de uma perspectiva de padronização e de desenvolvimento de técnicas de expressão escrita. Assim, elas propõem que a gramática seja abordada em sala de aula a partir do conhecimento linguístico prévio (gramática internalizada) que o estudante carrega para a escola. Nesse sentido, concordam com o procedimento de descoberta, defendido por Lobato (2003), que objetiva trazer à consciência dos estudantes conhecimentos que já possuem sobre sua própria língua. Para as autoras, à medida que o estudante verbaliza a língua, ele se apropria desse conhecimento e começa a manejá-lo e usá-lo como ponto de partida para o aprendizado de estruturas próprias da língua escrita aprendidas na escola.

Por conta dessa reflexão da língua baseada no que o aluno já sabe dela, as autoras sugerem que a organização dos conteúdos de LP seja feita pela REFLEXÃO $\rightarrow$ USO $\rightarrow$ REFLEXÃO $\rightarrow$ USO..., de forma que a reflexão anteceda ao uso. Elas propõem, então, reformular o eixo USO $\rightarrow$ REFLEXÃO $\rightarrow$ USO, proposto nos PCNs, que trata a gramática como algo secundário que surge à medida que os alunos vão produzindo seus textos, tomando a produção escrita como ponto de partida para a aprendizagem.

O professor, nessa nova proposta, prioriza a reflexão como origem do "ensino" de LP e, portanto, trabalha com as intuições que os estudantes têm acerca de sua própria língua, assumindo o papel fundamental de mediador, responsável por trazer à consciência do aluno (descoberta) as informações da sua gramática interna a partir da técnica de eliciação, que é extrair do aluno uma informação previamente conhecida antes de the apresentar um conteúdo novo, mostrando-Ihes que são parte ativa do processo de ensino-aprendizagem.

Uma distinção entre o trabalho de Lobato (2003) e o de Vicente \& Pilati (2012) é que, naquele, apesar de o papel de mediador que o professor tem no processo de 
ensino-aprendizagem não estar claramente expresso, concluímos, pelas etapas do método, que o professor promove a eliciação, sendo mediador de igual modo no processo. Em Vicente \& Pilati (2012), por sua vez, este papel fica explícito, essa ideia é claramente exposta e, por isso, tal trabalho pode ser considerado uma evolução, um complemento do trabalho de Lobato (2003).

\subsubsection{Formalismo e ensino de gramática na educação básica}

Pilati, Naves, Vicente \& Salles (2011) examinam a questão do "ensino" gramatical na educação básica argumentando que a abordagem formalista tem contribuição relevante para a formulação de propostas para o desenvolvimento do componente curricular de LP.

As autoras destacam que a relevância do "ensino" gramatical tem sido questionada em função de sua prática pedagógica estar associada ao "ensino" da norma padrão, que privilegia as formas linguísticas usadas em textos literários, ignorando o caráter dinâmico das línguas. Alega-se que as bases do "ensino" de gramática estão em desacordo com as demandas atuais da sociedade (uma cidadania letrada) e com os desenvolvimentos da Linguística e, por isso, esse ensino deve ser abolido.

As autoras se opõem à ideia de extinção do "ensino" de gramática e declaram que a Lei de Diretrizes e Bases (LDB) e os Parâmetros Curriculares Nacionais (PCNs) apontam caminhos em termos de competências e de habilidades a serem desenvolvidas e prezam pela interdisciplinaridade, apesar das abordagens e metodologias desses documentos poderem ser tratados como inacabadas. Nesse sentido, elas propõem o ensino de línguas vernácula e estrangeira baseado numa abordagem denominada educação linguística. Tal abordagem busca promover o estudo gramatical em uma perspectiva científica, "tendo em vista a existência de aparato(s) teórico(s) adequado(s) à caracterização das variedades linguísticas e de fenômenos gramaticais ligados às práticas discursivas" (PILATI et al., 2011, p.399). Assim, as línguas passariam a ser objeto de análise científica ao serem confrontadas com outras línguas pelo pressuposto da Faculdade da Linguagem e da Competência Linguística.

A partir desse raciocínio, Pilati et al. (2011) sugerem uma metodologia de formulação de hipóteses e raciocínio inferencial dos dados linguísticos baseada em projetos que desenvolvam as competências intelectuais dos alunos. 
Com isso, é esperado que habilidades linguísticas, como a capacidade de ler, interpretar e produzir enunciados, por um lado, e, por outro, a consciência em relação à natureza do conhecimento linguístico, se manifestem. Defendemos, portanto, que um objetivo fundamental do ensino de língua é desenvolver no aluno uma habilidade de reflexão sobre a língua que se torne cada vez mais refinada, com implicações para sua produção oral e escrita em língua portuguesa - e nas diferentes línguas a que tenha acesso, seja no caso das comunidades bilíngues, seja em relação à língua estrangeira (PILATI et al., 2011, p.400).

Segundo as autoras, as noções de Faculdade da Linguagem e de Competência são fundamentais, pois "esse conhecimento transcende uma língua particular, definindose por propriedades suficientemente abrangentes para abarcar as línguas em geral, e ainda suficientemente específicas, para comportar a ampla - e fascinante - diversidade linguística” (PILATI et al., 2011, p.400).

Esse entendimento também leva a uma mudança na formação do professor de língua, que precisa entender que o aluno já chega à escola com um conhecimento inconsciente de sua gramática interna e que sua função, então, é de tornar explícito esse conhecimento linguístico internalizado, é de trazer à consciência as estruturas da língua possibilitando ao aluno manipulá-la com os recursos gramaticais que possui.

Segundo Pilati et al. (2011), o problema é que a tradição gramatical, por adotar uma postura prescritiva ao extremo, promoveu uma inversão de valores em duas vertentes: (1) as aulas de gramática são aulas de "como usar a língua" em vez promover o entendimento de seu funcionamento e possibilidades; e (2) os estudantes não são ensinados a desenvolverem suas habilidades linguísticas e acabam sendo tratados como desconhecedores da língua que usam no dia a dia, ou seja, são colocados numa posição de aprendizado passivo, em que não se leva em consideração os conhecimentos que já possuem. Assim, as autoras destacam que o desafio do "ensino" de LP:

[...] está em formular a apresentação dos conteúdos, levando-se em conta o fato de haver um saber linguístico inato (GU): alguns aspectos não são ensinados, mas explicitados; outros aspectos são ensinados, porque correspondem a fenômenos da gramática definidos na interface com o discurso e com a pragmática ou ainda associados a uma decisão de ordem político-cultural, como, por exemplo, as condições que determinam o uso da variedade linguística de prestígio (e, consequentemente, de uso da norma padrão) (PILATI et al., 2011, p.403).

Para mudar esta situação, as autoras insistem que os cursos de licenciatura devem complementar a formação metodológica para o ensino para além das abordagens adotadas atualmente, que trabalham a língua como um fenômeno social ou com finalidade textual, pois a abordagem formalista é totalmente construtiva e eficiente no 
processo de ensino-aprendizagem, ou seja, uma abordagem não exclui a outra. Desta feita, Pilati et al. (2011) definem a ciência linguística como:

[...] um programa de pesquisa constituído por visões complementares de língua, ressaltamos que o ensino de língua no âmbito da educação formal não deve privilegiar nem um conceito nem outro, devendo, antes, abordar a língua sob ambas as perspectivas: a externa (desempenho) e a interna (competência) - a língua como um produto social e a língua como conhecimento gramatical internalizado (PILATI et al., 2011, p.402).

Para exemplificar a proposta alternativa, pautada no conceito de competência linguística, as autoras discutem três temas do estudo gramatical, desde a maneira como são tratados por diferentes gramáticos até os problemas causados por diferentes tratamentos para o ensino. São eles: funções sintáticas e transitividade, a regência verbal e a ordem das palavras.

Sobre as funções sintáticas e a transitividade, as autoras alegam que o principal problema para o ensino desse conteúdo está na falta de sistematicidade na formulação das definições das gramáticas tradicionais, que as apresentam de forma circular, um conceito depende do outro. Além disso, ainda há a questão de as gramáticas divergirem em relação à classificação dos verbos quanto à transitividade. Segundo as autoras, pela competência linguística, em geral, os estudantes conseguem distinguir as funções sintáticas e as relações gramaticais entre os verbos e seus complementos, assim como não constroem orações que estejam em desacordo com certos princípios da gramática de sua língua, sendo, portanto, capazes de lidar intuitivamente com as questões gramaticais. Com isso em mente, Pilati et al. (2011) defendem que o ensino deve buscar os dados a serem analisados na língua e, a partir daí, construir as definições. Esse movimento contrário à instrução normativa pode ser realizado a partir da produção e da compreensão de textos, lugar onde se materializa a gramática inconsciente interna dos alunos e que pode levá-los a refletir sobre a língua de forma consciente e intuitiva, buscando as regularidades e fazendo a relação entre a forma das expressões e a sua significação.

Quanto à regência verbal, as autoras afirmam que, apesar de o termo ter um significado amplo, sintaticamente falando, as gramáticas tradicionais limitam-se à regência pela preposição e a explicam a partir da distinção de significados pela ausência, ou não, da preposição. Isso leva a um ensino baseado na memorização, em que não se questionam os motivos pelos quais há, ou não, a flutuação da preposição, nem os contextos em que a presença ou ausência da preposição não fazem mais 
distinção de significados no português brasileiro informal. Para elas, um projeto educacional de investigação científica é o caminho para se alcançar as respostas a esses questionamentos, pois partiriam dos dados da língua, levando à problematização dos fatos e à discussão da descrição gramatical, acarretando, assim, a sistematização do conhecimento.

O fenômeno da ordem é tratado em duas partes. A primeira é a ordem dos termos no sintagma nominal, cujas análises, segundo as autoras, são mais complexas que as propostas na gramática normativa. Para elas, com a técnica da eliciação, o professor pode trabalhar as possibilidades e as restrições sintáticas na distribuição do sintagma nominal, assim como a correlação entre sua estrutura sintática e semântica, que muda o foco da aula da "classificação correta" para as "classificações possíveis" a depender da leitura semântica depreendida das construções. Esse processo extrairia dos alunos informações que, tradicionalmente, passariam de forma automática ou despercebida. A segunda parte diz respeito à ordem dos termos na oração e também propõe um "ensino" de gramática investigativo e que busque possibilidades de expressão. Para isso as autoras sugerem uma metodologia que se baseia na (1) apresentação e análise de dados, (2) eliciação das regras, (3) elaboração de conclusões e (4) prática textual.

Sintetizando, as autoras procuram:

[...] demonstrar que o pressuposto de que existe uma competência linguística inata e a proposta de educação linguística, em que a diversidade linguística constitui objeto de análise, permitem desenvolver práticas inovadoras para o trabalho com a gramática, propiciando a compreensão das propriedades das línguas em suas múltiplas manifestações, por um lado, e o desenvolvimento do uso consciente da língua, em função das demandas sociais, por outro (PILATI et al., 2011, p.423).

\subsection{Considerações do capítulo}

Os pressupostos gerativistas e os trabalhos que seguem essa teoria, como os de Lobato (2003), Pilati et al. (2011), Vicente \& Pilati (2012) e Pilati (2014) ${ }^{11}$, têm apresentado resultados importantes o "ensino" de língua materna. Os conceitos basilares da teoria gerativa podem significar uma nova visão ao professor que passa a ver o aluno como um indivíduo que chega à escola com uma gramática adquirida. A função da

\footnotetext{
${ }^{11}$ Para saber mais sobre o assunto, ver Frank (2006).
} 
escola, nesta perspectiva, é de aprimorar a gramática já constituída e utilizá-la para refletir sobre a estrutura da língua e para a aprendizagem da modalidade escrita.

O estudo de Kato (2005), por sua vez, representa um avanço para o entendimento das diferenças entre a fala e a escrita e reafirma a necessidade de reflexão por parte dos professores sobre a realidade do aluno ao chegar à sala de aula, dado que o discente chega com conhecimento linguístico inconsciente da língua e precisa tomar consciência do funcionamento desta. Outra questão importante discutida pela autora é a percepção do professor para identificar estruturas que precisam ser adquiridas e/ou aperfeiçoadas pelo aluno quando, na execução da escrita, ocorrem marcas da oralidade, dado que a periferia marcada é um subproduto da GU e que a gramática nuclear, da fala, é acessada quando as propriedades da periferia marcada ainda não estão apropriadas no nível necessário e/ou desejado.

Quanto às considerações de VanPatten, que são totalmente pertinentes para a discussão, destacando-se os conceitos de que (1) a aquisição envolve a criação de um conhecimento implícito inconsciente, mesmo que se tenha tido um aprendizado de regras explícitas através da aprendizagem formal em sala de aula; (2) a seleção criteriosa do input por parte do professor é fundamental; (3) a noção de que a regra precisa existir, mas o foco da aquisição deve ser o contexto comunicativo, sendo um produto da compreensão; e (4) o aluno acessa as estratégias de produção da L1 quando as estruturas adquiridas da L2 não dão conta da comunicação. Todos esses pontos levam o professor a refletir sobre sua prática docente e levam à compreensão de alguns fatos que ocorrem quando da aprendizagem da escrita em sala de aula.

Os pressupostos e conceitos apresentados nos permitem pensar sobre os problemas enfrentados na educação por parte de professores e alunos quanto ao conteúdo ministrado e às práticas docentes. De acordo com o panorama de Neves (1994), o “ensino" de gramática está relacionado a um único procedimento didático: exposição de conceitos e resolução de exercícios. Vimos que conhecimento explícito não é input, assim, esse método precisa ser reavaliado, pois a negligência às atividades de reflexão e de operação da linguagem prejudica o entendimento dos alunos sobre o funcionamento da língua.

Diante desses conceitos, foram apresentadas as sugestões metodológicas propostas por: (1) Lobato (2003), que consiste no procedimento de descoberta, na metodologia da eliciação e na técnica de resultados; (2) Vicente \& Pilati (2012), que defendem o "ensino" de gramática baseado no conhecimento linguístico prévio 
(gramática internalizada) concordando com o procedimento de descoberta de Lobato (2003) e com a eliciação, mas vendo esta última como uma técnica; e (3) por Pilati et al. (2011), que defendem a abordagem da educação linguística propondo uma metodologia de formulação de hipóteses e raciocínio inferencial dos dados linguísticos.

Sinteticamente, os trabalhos das autoras visam permitir ao aluno investigar e refletir sobre a estrutura da língua em funcionamento. Cabe deixar claro que, no contexto da escola, na educação formal, a não aplicação dessas sugestões não impede a aprendizagem do aluno. Entretanto, defende-se que, ao fazerem uso de conceitos como Faculdade da Linguagem, Gramática Internalizada, Competência Linguística e Criatividade, o processo de ensino-aprendizagem se torne mais eficiente, além de instigar o professor a ter um novo olhar sobre o próprio conceito de gramática, o que implica a revisão, mais que necessária, das práticas docentes.

Enfim, analisando as obras apresentadas, pode-se observar que elas abrangem de maneira consistente as discussões atuais concernentes a questões do "ensino" de LP. A linguística gerativa tem contribuído de fato com conceitos que podem mitigar os problemas enfrentados no "ensino" de língua materna e trazer uma mudança significativa ao ensino. A necessidade de inovação nas práticas pedagógicas é iminente e estudos linguísticos, como os vistos neste trabalho, têm comprovado o atraso e a ineficiência das metodologias utilizadas na escola. Apesar de já existirem sugestões metodológicas sob o olhar gerativista, uma sistematização das propostas ainda é necessária, para que realmente haja mudança nas práticas docentes. A teoria e a reflexão estão postas, mas a orientação prática, até este momento, parece ser deficitária.

Em resumo, os estudos expostos e as sugestões metodológicas apresentadas nos levam a defender que uma proposta pedagógica ideal para as aulas de LP, incluindo as de gramática, parta da:

(1) gramática internalizada (conhecimento prévio do aluno),

(2) reflexão linguística (com atenção ao input fornecido); e

(3) aprendizagem em contexto comunicativo que gere compreensão. 


\section{Capítulo 2}

\section{Aprendizagem ativa e "ensino" de gramática: repensando a metodologia}

O presente capítulo aborda estudos sobre os processos de aprendizagem, bem como trabalhos baseados nos princípios gerativistas que colocam em prática toda a discussão do capítulo anterior. Nesse sentido, apresentam-se os trabalhos de Pilati (2014) e Bransford et al. (2007), Silva (2015) e Pilati, Sandoval e Zandomênico (2016).

\subsection{A importância da aprendizagem ativa}

A ciência da aprendizagem ou ciência cognitiva, que se iniciou no final do século XIX, trouxe novos conceitos fundamentais sobre como ocorre o processo de aprendizagem.

A pesquisa da aprendizagem indica que há novas maneiras de apresentar as matérias tradicionais para os estudantes [...] e que essas novas abordagens tornam possível o desenvolvimento de uma compreensão mais profunda do assunto relevante para a maioria das pessoas (BRANSFORD et al., 2007, p.22).

Essa nova ciência tem como marco a aprendizagem com entendimento para gerar "conhecimento utilizável", que é a capacidade de organizar conceitos importantes para o entendimento do conteúdo e sua posterior transferência, ou seja, uso em outros contextos. Essa capacidade é, inclusive, uma das características que difere especialistas de principiantes em determinada área, já que estes usam a capacidade de recordar para resolução de situações-problema, o que os limita à capacidade da memória e/ou de já terem visto situação semelhante previamente. Aqueles, por sua vez, acessam os conhecimentos importantes aprendidos e aplicáveis à situação proposta para chegarem a uma resolução. Desta forma, mesmo que seja uma situação nunca vista, os especialistas conseguem resolvê-la, pois se valem de conhecimentos basilares aplicáveis em situações distintas, ou seja, dotados de informações cruciais e treinados a pensar, eles aplicam os conceitos aprendidos à situação dada.

O conhecimento dos especialistas não é simplesmente uma lista de fatos e fórmulas relevantes para seu campo de autuação; seu conhecimento se organiza, na verdade, em torno de conceitos essenciais ou "grandes ideias" que orientam seu raciocínio (BRANSFORD et al.,2007, p.19). 
Aplicando essas ideias à sala de aula, o objetivo da escola, portanto, deve ser transformar os alunos em pequenos especialistas, ensinando-os a pensar, a organizar os conhecimentos que possuem juntamente com as informações dadas à determinada situação para raciocinar e alcançar resultados. Mas como se daria esse processo?

Pilati (2014) apresenta as teorias, utilizadas na disciplina Laboratório de Ensino de Gramática, buscando soluções para os problemas metodológicos das aulas de gramática e objetivando formar professores com uma nova postura didática. A autora ressalta duas dimensões básicas do ensino das quais os professores precisam ter consciência, quais sejam: a necessidade de o ensino "promover o desenvolvimento de habilidades mentais complexas e profundas" (PILATI, 2014, p. 55) e o entendimento que cada área do conhecimento tem características e especificidades que devem ser levadas em consideração durante atividades de ensino e aprendizagem e que o professor deve dominá-las.

A autora declara que a abordagem do "ensino" de gramática deve ser bem estabelecida para servir de parâmetro na atuação docente. Assim, a abordagem deve responder a perguntas como: O que é uma língua? Como se adquire? Como se ensina? Como se aprende? O professor deve estar preparado para responder esses tipos de questões e ainda deve estar pronto a ensinar especificidades da modalidade escrita, uma modalidade nova que o aluno aprende na escola.

Adotando a perspectiva gerativista, Pilati (2014) corrobora a discussão sobre a importância do input e a diferença da gramática da fala e da escrita ao defender que a exposição dos dados linguísticos, o tipo de informação linguística oferecida, os recursos didáticos usados, entre outras questões, devem ser minuciosamente observados pelo professor, levando em consideração que a fala é o conhecimento inconsciente de aspectos da língua adquiridos pela Faculdade da Linguagem associada ao input, enquanto a escrita é a associação da Faculdade da Linguagem com conceitos aprendidos na escola. Em suma, a fala é inata e abrange uma série de conhecimentos inconscientes da língua, já a escrita não e, por isso, tem que ser aprendida na escola. O que relaciona as habilidades de fala e de escrita é o "conhecimento linguístico explícito"12, que é a ação de explicitar e demonstrar como funcionam certos fenômenos linguísticos.

Para que o conhecimento linguístico implícito se torne explícito, Pilati (2014) defende que os estudantes precisam entender o sentido dos assuntos apresentados para

\footnotetext{
${ }^{12}$ Termo adotado por Costa et al. (2010).
} 
que ocorra uma aprendizagem efetiva e ativa. Isto é, uma aprendizagem em que aluno participa do método e compreende os processos envolvidos no conteúdo a ser estudado para entendê-lo de fato, captando, assim, os princípios e o funcionamento da língua.

A partir dos conceitos apresentados em Bransford et al. (2007), Pilati (2014) destaca três princípios que devem ser seguidos para promover o aprendizado efetivo da LP em sala de aula:

$\left.1^{\circ}\right)$ considerar o conhecimento prévio do aluno, pois "é importante mostrar aos alunos o funcionamento da língua humana sob diferentes perspectivas para que possam compreender o próprio objeto de estudo e os objetivos das aulas de português" (PILATI, 2014, p. 61). Segundo Bransford et al. (2007, p.27), "as pessoas elaboram o novo conhecimento e o entendimento com base no que já sabem e naquilo que acreditam”, por isso, esse conhecimento prévio também deve receber atenção para que o novo conhecimento não seja prejudicado por crenças falsas e interpretações ingênuas e/ou incompletas. É preciso esclarecer o conhecimento prévio do aluno para se ter certeza que a nova informação está sendo recebida de forma completa e genuína;

$2^{\circ}$ ) promover aprendizagem ativa, ou seja, uma aprendizagem em que aluno participa do processo e compreende realmente o assunto a ser estudado. É a aprendizagem que leva à metacognição, "capacidade de uma pessoa prever o próprio desempenho em diversas tarefas e de monitorar seus níveis atuais de domínio e compreensão" (BRANSFORD et al., 2007, p.30), gerando autonomia e autocontrole sobre a aprendizagem;

$3^{\circ}$ ) levar o aluno a compreender os processos envolvidos no assunto estudado, sendo necessário o acesso a uma base sólida de conhecimento factual que permita aos estudantes entender o contexto e organizar o novo conhecimento para recuperá-lo com facilidade, tornando-os especialistas com o passar do tempo.

Tais princípios conduzem a consequências diretas para o ensino, quais sejam:

- os professores devem "extrair" a compreensão preexistente dos alunos, o que nos remete à Faculdade de Linguagem de Chomsky (1965) e à metodologia da eliciação de Lobato (2003); 
- a abordagem metacognitiva deve ser aplicada nas diversas áreas temáticas e integrada ao currículo;

- os assuntos devem ser ensinados em profundidade e com bastantes exemplos para que os alunos vejam o conceito estudado em diferentes contextos e formem sua base de conhecimento factual.

O ambiente escolar também é ponto fundamental discutido pela ciência cognitiva. As escolas devem projetar ambientes de sala de aula centrados no aluno, onde se preste atenção ao "o que", ao "por que" e ao "como" é ensinado. Nesse sentido, as avaliações formativas, contínuas, são ferramentas importantes, pois permitem o monitoramento de todo o processo de aprendizagem.

Outro ponto importante a se destacar é a questão da transferência, "capacidade de estender o que se aprende em um contexto a novos contextos" (BRANSFORD et al., 2007, p.77). Entre outros fatores, o grau de domínio do assunto original influencia a transferência bem sucedida, porque envolve a aprendizagem com compreensão, o tempo de ensino necessário para os diferentes assuntos, uns mais complexos que outros, e a motivação para aprender.

Para Bransford et al. (2007), a transferência é o principal meio de avaliar a aprendizagem porque afere o que é aprendido com o que é testado. Ela pode ser ativa (dinâmica), composta por análise de situações e elaboração de estratégias, ou passiva (mecânica), baseada na repetição. Da mesma forma que a aprendizagem tem que ser ativa, a transferência também deve ser, com atividades que exijam do aluno análise e resolução de problemas empregando o conteúdo aprendido, ou seja, é preciso fazer o aluno pensar. Silva (2015) relaciona a capacidade de transferência à técnica de resultados compreendida na metodologia de Lobato (2003), afirmando que se assemelham. Além dessa semelhança, pode-se relacioná-la ao output de VanPatten (2003), uma vez que é o resultado produzido pela aprendizagem.

Para além de aplicação de conceitos aprendidos na escola, a transferência está presente em todo o processo de aprendizagem, desde o conhecimento prévio do estudante, que é preciso ser levado em consideração para que haja uma transferência para os novos conteúdos, até a transferência de um conteúdo para outro, de uma série para outra, da escola para a vida e vice-versa, sendo uma questão imprescindível no que tange ao ambiente escolar. 
Saindo da esfera teórica, Pilati (2014) apresenta três práticas linguísticas que buscam promover o conhecimento linguístico explícito e contribuir para uma nova prática docente, levando em consideração os pressupostos gerativistas e os conceitos da ciência cognitiva. As práticas consistem em atividades desenvolvidas na disciplina Laboratório de Ensino de Gramática a fim de promover a aprendizagem ativa e o entendimento do funcionamento da língua, são elas:

a) proposta lúdica de oficina sobre as estruturas linguísticas a partir de material reciclado com o objetivo de tirar tais estruturas do plano abstrato e levá-las ao plano concreto para que o aluno possa visualizá-las e, consequentemente, facilitar sua compreensão. Aspectos como formação de palavras, estrutura de constituintes, estrutura das sentenças e relação forma e significado podem ser trabalhados;

b) análise de aspectos gramaticais em poemas e trechos literários a partir da investigação, da identificação e da análise dos recursos sintáticos empregados pelos poetas em seus textos. É uma atividade que requer do aluno a capacidade de análise de fenômenos e o entendimento dos resultados estilísticos originários de diferentes construções linguísticas, além de permitir-Ihes estabelecer contato com várias produções literárias, sendo um input diferenciado; e

c) atividades de revisão e reescrita textual que, embora pouco usadas nas aulas de gramática, têm grande importância por permitir ao aluno estabelecer padrões, praticar o senso crítico e identificar desvios de norma ${ }^{13}$. A autora defende que, por meio da revisão textual, o aluno terá acesso a diferentes estruturas linguísticas e poderá avaliar textos de diversas naturezas, acessando e ampliando sua base sólida de conhecimento factual para facilitar a recuperação e a aplicação do conhecimento nos contextos adequados, ou seja, o aluno pratica constantemente a transferência dos assuntos estudados.

A autora se baseia numa abordagem de aprendizagem ativa permeada por toda a discussão do capítulo anterior no que se refere à Competência Linguística, à falta de

\footnotetext{
${ }^{13}$ Aqui, não se faz referência especificamente à normal padrão, leva-se em consideração o tipo de registro adotado para poder identificar os desvios pertinentes a ele.
} 
modelos práticos para auxilio dos discentes, à ineficácia da abordagem baseada na memorização e à importância da aprendizagem com compreensão.

Além de corroborar a discussão sobre a importância do input e a diferença da gramática da fala e da escrita de Lobato (2003), as ideias de Pilati (2014) remetem ao estudo de Vanpatten (2003) ao defender que o foco da aquisição é o contexto comunicativo e que ela ocorre como um produto da compreensão, quando o aprendiz faz conexões entre o significado e como o significado está codificado. Ou seja, a aula de gramática, o trabalho com a língua escrita em contexto educacional, precisa incluir a situação comunicativa para ser efetiva.

A autora, para além de apontar os problemas, busca soluções inovadoras ao propor e ensinar, na disciplina Laboratório de Ensino de Gramática, atividades que promovem o conhecimento linguístico explícito, permitindo um aprendizado ativo a partir da reflexão da língua.

Apesar de ainda faltar sistematizar a proposta, orientação prática, essa iniciativa proporciona maior suporte aos novos professores e pode ser considerada, a depender da dissipação desse conhecimento, uma colaboração na melhoria do ensino no Brasil.

Dentre as atividades propostas por Pilati (2014), temos a prática de revisão e reescrita textual. $\mathrm{O}$ trabalho da autora foi o gérmen para esta dissertação, que busca, exatamente, fazer um apanhado teórico dos estudos que propõem a reflexão linguística, a revisão e a reescrita textuais nas aulas de gramática, além de desenvolver uma sequência didática na tentativa inicial de aferir como e se os benefícios atribuídos às atividades de revisão e reescrita acontecem e se são passíveis de serem utilizados efetivamente em sala de aula, podendo essa atividade ser denominada, então, como uma prática de ensino.

\subsection{Estudo de caso sobre o desenvolvimento da consciência sintática em sala de aula}

Silva (2015) analisa os PCN's (BRASIL, 1997) e o Guião de Implementação do Programa de Português do Ensino Básico (2011), diretrizes para o ensino de LP adotadas no Brasil e em Portugal, respectivamente. Ela conclui que os PCN's (BRASIL, 1997) mostram apenas diretrizes gerais com uma abordagem sociointeracionista, não há métodos e técnicas definidos. Em contrapartida, o Guião (2011) traz diretrizes com 
abordagem, método e técnica definidos com exemplos de práticas que retratam as questões levantadas pelo documento.

Como lado positivo, destaca-se a abordagem ativa de descoberta no processo de aprendizagem considerada por ambos os documentos. O Guião (2011) propõe essa abordagem destacando a competência Conhecimento Explícito da Língua.

\begin{abstract}
De acordo com a obra, o Conhecimento Explícito da língua pressupõe a existência de um conhecimento implícito. Afirmar a existência do conhecimento implícito implica dizer que ativamos todos os níveis gramaticais de forma inconsciente e eficiente. Ao entendermos isso, conseguimos entender que ensinar gramática não é ensinar algo completamente novo, mas, sim, tornar os nossos alunos conscientes de um conhecimento que eles têm e aplicam, mas do qual não têm consciência (SILVA, 2015, p.49).
\end{abstract}

Para aferir a efetividade do Guião (2011), que se alinha aos pressupostos teóricos discutidos e se propõe a desenvolver a consciência linguística dos alunos, a autora elabora uma atividade gramatical seguindo um modelo apresentado no documento. Ela, entretanto, faz adaptações na atividade a partir de uma crítica levantada sobre o documento.

Diferentemente da técnica adotada pelo Guião (2011), nessa atividade, os conhecimentos são vinculados à produção textual e não apenas testados com a marcação de tabelas. Buscou-se fazer com que os alunos fossem capazes de desenvolver não apenas o conhecimento gramatical, mas, também, as habilidades de escrita, leitura e revisão textual (SILVA, 2015, p.68).

A atividade desenvolvida teve como tema a identificação e classificação do sujeito e do predicado e foi aplicada em uma turma de $7^{\circ}$ ano do Ensino Fundamental. Como ela é extensa, faremos um breve resumo do que foi proposto, a atividade na íntegra se encontra no Anexo I:

$\underline{\text { Etapa } 1}$ - Procedimento de descoberta: Identificação do tipo de elemento que pode ocupar a função de sujeito com o objetivo de fazer com que os alunos percebam, a partir da análise dos dados de forma intuitiva, que há o critério semântico e o sintático para o sujeito e o predicado estabelecerem relação. Destaca-se um verbo (Anunciaram) e elenca-se uma série de elementos ("as cadeias", "os jornais", “o jovem", "os funcionários" e "a menina"), perguntando quais deles poderiam ter praticado a ação expressa pelo verbo. Após, há diferentes questionamentos do porquê de alguns termos poderem ocupar essa posição e outros não. Depois se apresenta um quadro com os conceitos de critério semântico e sintático. Ao final de cada etapa, não apenas desta, há uma questão com o objetivo de resumir o que foi visto naquela parte do processo. 
Etapa 2 - Técnicas de Eliciação: Relacionamento entre nomes e verbos para a construção de critérios para as classificações. Os alunos correlacionam uma coluna com nomes a outra com verbos, justificando essa relação e outras possíveis que são questionadas. "Espera-se, nessa etapa, que os alunos consolidem sua aprendizagem com a aplicação do conteúdo a diferentes contextos [...]” (SILVA, 2015, p.77).

Etapa 3 - Construção das regras: Busca-se desenvolver o "conhecimento linguístico profundo". Numa série de frases, os alunos separam o verbo e fazem a pergunta "quem?" a ele para identificarem o sujeito. Esse mecanismo funciona com alguns, mas não com outros e os alunos são solicitados a justificar o motivo. Também se pede para separar as frases em dois grupos, um que tem os sujeitos expressos e outro com os não expressos e depois se apresenta um novo quadro separando o sujeito não expresso em "identificável" e "não-identificável". Após, apresentam-se os sujeitos simples e composto e pede-se para separar as frases com sujeitos expressos nestas duas classificações. Silva (2015, p.78) declara que nesta etapa:

Espera-se que os alunos estabeleçam os conceitos para a classificação dos diferentes tipos de sujeito, a partir da identificação das formas verbais; da pergunta "Quem?"; da presença ou não do sujeito na oração, se expressos ou não-expressos; da capacidade de serem identificados, ou não; da classe gramatical que ocupa a função de sujeito e da quantidade de núcleos que o sujeito apresenta.

$\underline{\text { Etapa } 4}$ - Aplicação das regras a contextos diversos: modificam-se as estruturas da oração com inversões e interposições para mostrar que o sujeito pode aparecer de diversas formas. Técnica de resultados que procura evidenciar que, mesmo em estruturas desconhecidas, os critérios estudados são eficazes na identificação do sujeito.

$\underline{\text { Etapa } 5}$ - Avaliação por meio de revisão de texto: aplicação dos conteúdos estudados para torná-lo conhecimento utilizável. Apresentam-se dois textos, no primeiro, pede-se para identificar os sujeitos dos verbos destacados e, no segundo, além de identificar o sujeito, solicita-se a reescrita com a correção dos problemas de concordância entre verbo e sujeito. "A revisão de textos tem o intuito de fazer com que os alunos reconheçam os padrões identificados nas etapas anteriores e saibam mobilizar o conhecimento para a resolução da situação-problema proposta, no caso, a correção do texto" (SILVA, 2015, p.78). 
Etapa 6 - Sistematização do conteúdo: apresenta-se um diagrama que os alunos têm que completar os critérios para relacionar o sujeito ao verbo e os tipos de sujeitos (expresso simples, expresso composto, não-expresso identificável, não-expresso nãoidentificável). O esquema permite a visualização e sistematização dos conceitos, além de ser uma forma de revisão do conteúdo.

Para a apuração dos resultados, Silva (2015) aplicou as etapas 5 e 6, concernentes à avaliação e sistematização, em duas turmas, uma que fez toda atividadeteste proposta (etapas 1 a 6) e outra que estudou o conteúdo pelas atividades do material didático adotado pela escola e realizou somente as etapas 5 e 6 . Na grande maioria dos itens das etapas avaliadas (5 e 6), a turma que passou por todo o teste alcançou melhores resultados que a turma que usou o material didático regular, assim, de modo geral, o material elaborado apresentou resultados positivos. Tais resultados são bons indícios de que a abordagem do aprendizado pela descoberta pode cooperar positivamente para o "ensino" da modalidade escrita da língua materna. Sobre isso, Silva (2015, p.6) declara:

Os alunos que tiveram contato com o material didático desenvolvido demonstraram uma nítida associação do conteúdo estudado ao conhecimento de mundo que possuem. Pode-se perceber que a abordagem do aprendizado pela descoberta, com metacognição, revela-se um caminho promissor no ensino de língua materna, porque foi possível notar a evolução das respostas dos alunos, com relação à complexidade e ao uso das terminologias e o desenvolvimento do raciocínio destes diante das análises.

Esse estudo reforça as discussões anteriores sobre conhecimento prévio, aprendizagem ativa e metacognição, entre outros conceitos abordados e as complementa com a elaboração e a testagem de uma atividade que evidencia a efetividade da contribuição dos pressupostos da teoria gerativa, juntamente com as ideias da ciência cognitiva, para o ensino. Nessa atividade, tem-se a revisão textual como forma de avaliar e revisar o conteúdo estudado.

Ainda que as atividades de revisão e reescrita textual não sejam o foco deste trabalho, é possível perceber seu uso a partir de uma abordagem de aprendizagem ativa que tem total relação com os pressupostos gerativistas discutidos. Assim, o trabalho de Silva (2015) representa um estudo prático inicial na área com resultados satisfatórios e inspiradores. 


\title{
2.3 Práticas inovadoras para a sala de aula de gramática
}

Pilati, Sandoval e Zandomênico (2016) objetivam dar continuidade às ideias apresentadas em Pilati (2014), acrescentando uma proposta de atividade prática subsidiada pelas seguintes concepções: promoção do conhecimento linguístico explícito e percepção e compreensão de fenômenos básicos presentes nas estruturas da LP. As autoras defendem que, além das contribuições já mencionadas em Pilati (2014), as atividades de revisão textual podem ajudar no desenvolvimento de diversas habilidades cognitivas ligadas ao letramento, tais como a leitura e a compreensão dos sentidos do texto.

A revisão textual também pode ser útil para que se desenvolvam habilidades e competências educacionais defendidas nos PCNs, ao ativarem a consciência do aluno em relação a: produção de textos como atitudes discursivas, importância das escolhas textuais conscientes e não aleatórias, adequação das formas linguísticas aos diferentes gêneros textuais, entre outros. O trecho abaixo, retirado dos PCNs (1997, p.22), confirma a importância do desenvolvimento de tais habilidades, quando afirma que:

\begin{abstract}
Produzir linguagem significa produzir discursos. Significa dizer alguma coisa para alguém, de uma determinada forma, num determinado contexto histórico. Isso significa que as escolhas feitas ao dizer, ao produzir um discurso, não são aleatórias — ainda que possam ser inconscientes —, mas decorrentes das condições em que esse discurso é realizado. Quer dizer: quando se interage verbalmente com alguém, o discurso se organiza a partir dos conhecimentos que se acredita que o interlocutor possua sobre o assunto, do que se supõe serem suas opiniões e convicções, simpatias e antipatias, da relação de afinidade e do grau de familiaridade que se tem, da posição social e hierárquica que se ocupa em relação a ele e vice-versa. Isso tudo pode determinar as escolhas que serão feitas com relação ao gênero no qual o discurso se realizará, à seleção de procedimentos de estruturação e, também, à seleção de recursos linguísticos. É evidente que, num processo de interlocução, isso nem sempre ocorre de forma deliberada ou de maneira a antecipar-se ao discurso propriamente. Em geral, é durante o processo de produção que essas escolhas são feitas, nem sempre (e nem todas) de maneira consciente.
\end{abstract}

Para Pilati (2014), as atividades de revisão e reescrita textual são de extrema importância para que o aluno seja capaz de reconhecer padrões linguísticos e passe a fazer suas escolhas linguísticas de maneira cada vez mais consciente. Também são importantes para que ele coloque seu senso crítico em prática e aprenda a identificar desvios de norma. Por meio da revisão textual, o aluno terá acesso a diferentes estruturas linguísticas e poderá avaliar - com a ajuda do professor, num primeiro momento, e depois cada vez mais independentemente - textos de diversas naturezas. 
A revisão textual, que pode ser feita em grupo ou individualmente, serve para que o aluno desenvolva a consciência de aspectos linguísticos que devem ser observados nos textos escritos. Acredita-se que, por meio dessa atividade, os alunos serão capazes de acessar uma base sólida de conhecimento factual, entender os fatos e as ideias no contexto e organizar o conhecimento, a fim de facilitar a recuperação e a aplicação do que foi aprendido nos contextos adequados, isto é, a transferência.

A partir das considerações acima, as autoras descrevem um roteiro para orientar os professores na adoção da revisão e reescrita textual nas aulas de gramática como uma prática de desenvolvimento/aperfeiçoamento das habilidades linguísticas dos discentes.

Inicialmente, elas orientam a divisão da turma em pequenos grupos de dois a quatro alunos cada, esclarecendo que a atividade pode ser feita individualmente, mas apenas em uma etapa posterior, quando os alunos já demonstrarem certa segurança para avaliarem os textos sozinhos. As autoras sugerem, ainda, uma atividade para uma turma de oitavo ano em diante, seguindo as etapas abaixo discriminadas:

- $1^{\text {a }}$ etapa: selecionar textos e distribuir um para cada grupo. O texto pode ser de autoria dos alunos ou não, devendo-se tomar cuidado com a possibilidade de identificação do autor para evitar constrangimentos;

- $\underline{2}^{\mathrm{a}}$ etapa: pedir que cada grupo leia seu texto integralmente (leitura 1), o professor também pode fazê-lo, se preferir. O objetivo é permitir que os alunos tomem conhecimento do assunto de que trata o texto e tenham uma ideia geral de como o texto está organizado. Nessa etapa devem ser reconhecidos e analisados criticamente elementos textuais tais como: emissor, receptor, publicoalvo, gênero e tipo textual, o que contribuirá para a construção dos sentidos do texto.

- $3^{\text {a }}$ etapa: fazer uma nova leitura (leitura 2), período por período, identificando e destacando todos os verbos presentes no texto. É importante que o texto original se mantenha intacto para que, ao final do processo, possa-se comparar os resultados. Por isso, sugere-se que cada grupo tenha duas cópias do texto e também folhas adicionais para sugestões de reescrita durante as análises, "uma vez que devem fazer parte do processo de revisão de texto propostas de 
reformulação de trechos mal estruturados, ambíguos, redundantes, pouco claros etc.” (PILATI, SANDOVAL E ZANDOMÊNICO, 2016, p.9);

- $4^{\text {a }}$ etapa: identificar os sujeitos de cada oração, uma vez que os verbos já estão demarcados. O objetivo dessa etapa consiste em: (i) verificar se os períodos do texto são formados por orações completas, sem truncamentos sintáticos; (ii) avaliar se as orações apresentam sujeito facilmente identificável, de forma que favoreçam a veiculação das ideias de forma clara e coerente; (iii) constatar se as regras de concordância verbal foram empregadas adequadamente no texto, de forma que sejam respeitadas as regras da língua formal escrita; entre outros (PILATI, SANDOVAL E ZANDOMÊNICO, 2016). À medida que forem constatados desvios da norma, os alunos devem fazer as devidas correções;

- $5^{a}$ etapa: releitura do texto (leitura 3) para identificação dos elementos de referenciação e retomada empregados (pronomes, repetição dos nomes já empregados ou substituição desses por novos etc.). De igual modo, fazer as alterações que se acharem necessárias. "Essa etapa avança com relação à anterior pelo fato de ser necessário observar mais atentamente a relação existente entre os períodos do texto" (PILATI, SANDOVAL E ZANDOMÊNICO, 2016, p.10). Em seguida à análise dos elementos de referenciação e retomada (que seria uma outra etapa), ou concomitantemente a ela, a depender do nível de domínio de conhecimento gramatical dos alunos, solicitar que identifiquem os conectores do texto e avaliem se as circunstâncias que exprimem estão adequadas ao contexto em que foram empregados, se não estiverem, pedir para proporem uma reescrita. Vale, também, observar se há estruturas inadequadas no que tange à regência verbal e nominal, pois podem alterar o sentido;

- $\quad \underline{6^{a}}$ etapa: análise da seleção e adequação vocabular. Chamar a atenção dos alunos para o registro apropriado segundo o gênero e tipo textual; 


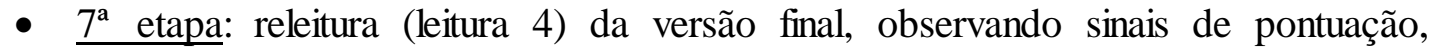
grafia e adequação das palavras. Esta leitura deve ser mais global, já com o texto como uma unidade coesa e com seus sentidos construídos.

Ao final, é importante que haja troca de conhecimentos de modo que todos os alunos vejam o trabalho realizado por todos os grupos. Isso pode se dar por meio de apresentação, do professor ou do próprio grupo, da proposta de reformulação elaborada como resultado do processo.

Pilati, Sandoval e Zandomênico (2016, p.11) ressaltam, ainda, que a intervenção do professor é necessária e fundamental:

O professor pode e deve auxiliar os alunos durante o processo de revisão dos textos. Esse procedimento conduzirá os alunos ao longo do trabalho e dará a eles a segurança de que precisam para, posteriormente, revis arem seus textos por si mesmos.

Por fim, as autoras declaram que os aspectos avaliados no roteiro podem variar segundo o nível de conhecimento dos alunos e que o fator tempo é muito importante, pois atividades desse tipo demandam muito tempo de aula, além de atenção e dedicação do professor. Apesar disso, as atividades de revisão e reescrita são uma estratégia necessária porque os benefícios que trazem suplantam a questão de serem trabalhosas, uma vez que permitem o reconhecimento e o uso da riqueza e da flexibilidade da língua. Por isso, elas devem ser regulares nas aulas durante todo o ano letivo para que os alunos entendam a importância desse processo e que ele passe a ser habitual em suas produções textuais.

As autoras, portanto, procuram mostrar de que forma os estudos linguísticos podem ser efetivamente úteis nas aulas de gramática, sendo um aprofundamento das ideias de Pilati (2014) por sistematizar a proposta apresentada, mostrando roteiro prático de aplicação. Além disso, ao denominar a "Abordagem Linguística das Línguas Naturais", Pilati, Sandoval e Zandomênico (2016) nomeiam a abordagem ativa que tem permeado as discussões desta dissertação.

Mantendo-se fiel a essa abordagem, vê-se, na proposta de atividade, que a todo tempo o aluno é o protagonista do aprendizado e o professor é o mediador do processo. Assim, o texto pode ser considerado exemplo de possibilidade real de promover aprendizado efetivo, a partir de uma postura didática inovadora que prima por aulas em que o entendimento dos alunos acerca dos conteúdos gramaticais seja o foco, e não a sua mera memorização. 


\subsection{Considerações do capítulo}

O capítulo apresentou os estudos de Bransford et al. (2007) e Pilati (2014) sobre processos de aprendizado baseados em abordagem de aprendizagem ativa, além de reforçar as ideias do capítulo anterior ao (1) defender o uso do conhecimento prévio do aluno, (2) ressaltar a importância do input, (3) diferenciar a gramática da fala e a da escrita e (4) afirmar que o foco da aquisição deve ser o contexto comunicativo. Houve, ainda, a exposição dos trabalhos de Silva (2015) e Pilati, Sandoval e Sandomênico (2016), que, na tentativa de produzir um modelo teórico para a prática docente, elaboraram atividades baseadas na prática da revisão e da reescrita textual para promover a consciência sintática nas aulas de gramática a partir dos pressupostos estudados.

Percebe-se, portanto, as discussões do capítulo 1 sendo postas em prática e a importância e maior participação da revisão e da reescrita textual para promoção da consciência linguística. Por fim, o capítulo ressalta a progressão contínua dos estudos gerativistas e afins ligados ao ensino que defendem o aluno como agente principal no processo de aprendizagem. Os exemplos de atividades propostas são mais um passo para o avanço das discussões linguísticas do tema. 


\section{Capítulo 3}

\section{Projeto Piloto: aplicação de técnica e resultados}

Após todo esse percurso de discussão de ideias e exposição de trabalhos e técnicas que já se tem em campo, convergiram-se os pressupostos da teoria gerativa e sua ligação com o ensino com as descobertas da ciência cognitiva, buscando aferir a efetividade dos conceitos discutidos em uma aula de gramática. Ou seja, pôs-se em prática tudo que foi estudado através da aplicação de um projeto piloto tendo como base a reflexão linguística e a revisão e reescrita textual.

Este capítulo traz com minúcias a proposta do projeto, sua aplicação e os resultados alcançados.

\subsection{O Projeto Piloto}

O objetivo do Projeto Piloto foi elaborar uma sequência didática que refletisse as proposições elaboradas ao longo deste trabalho, isto é, utilizar o conhecimento prévio do aluno, a reflexão linguística e as atividades de revisão e reescrita textual baseado na aprendizagem com compreensão.

A ideia foi aplicar a sequência em uma turma e, em uma segunda turma, ministrar uma aula de gramática normativa, seguindo a metodologia tradicional (da mera exposição de dados). Após, ambas as turmas fizeram uma atividade avaliativa a fim de comparar a assimilação e o entendimento do conteúdo entre as turmas.

Como última etapa do processo, uma avaliação da proposta pedagógica foi submetida às duas turmas por meio de um questionário elaborado de maneira sucinta para aferir a predileção dos discentes para a sequência didática proposta ou para a aula de gramática tradicional.

Desta feita, a sequência didática foi praticada em uma turma de terceiro ano do Ensino Médio, pela maior maturidade, comportamental e linguística, que se espera dos alunos nesta série, no Centro Educacional Asa Norte (CEAN). Para manter o ambiente de aprendizagem conhecido dos alunos e não interferir em seus comportamentos, a professora de LP da turma ministrou as aulas e aplicou as atividades. Todo o processo teve duração de quatro aulas. 
Neste trabalho, a turma em que a sequência didática teste foi aplicada será denominada Turma CS (Consciência Sintática). A Turma TR (Tradicional), por sua vez, refere-se à turma que em que foi ministrada a aula tradicional.

Em ambas as turmas, 25 alunos realizaram as atividades de forma completa, participando da aula e fazendo a atividade e sua respectiva avaliação. Segundo a professora, na Turma CS, os alunos se mostraram atentos à proposta e participaram efetivamente da aula, respondendo às provocações que a professora fazia e levantando questionamentos para sanar dúvidas e citar outros exemplos. Já na Turma TR, os alunos apenas copiaram a matéria e prestaram atenção à explicação, tanto da disciplina quanto da atividade avaliativa. Ainda segundo a professora, ficou clara a diferença de interesse pela aula entre as turmas participantes. Essa impressão se confirma pelos resultados aferidos e descritos adiante.

\subsection{A sequência didática}

A sequência didática foi criada levando em consideração:

- As propostas metodológicas estudadas: o procedimento de descoberta, a técnica de eliciação e de resultados de Lobato (2003), o "ensino" de gramática baseado no conhecimento linguístico prévio (gramática internalizada) de Vicente \& Pilati (2012) e uma metodologia de formulação de hipóteses e raciocínio inferencial dos dados lingüísticos de Pilati et al. (2011);

- Os princípios de Bransford et al. (2007), reforçados por Pilati (2014), de (1º) considerar o conhecimento prévio do aluno, $\left(2^{\circ}\right)$ promover aprendizagem ativa e $\left(3^{\circ}\right)$ levar o aluno a compreender os processos envolvidos no assunto estudado;

- Os aprendizados decorrentes dos testes apresentados em Silva (2015) e Pilati Pilati, Sandoval e Zandomênico (2016).

Em resumo, tal sequência foi baseada na abordagem que adere a concepção de gramática internalizada e de "conhecimento utilizável" com uma metodologia que se pauta no uso do conhecimento prévio do aluno, na reflexão linguística e na aprendizagem com compreensão, levando a um método que proporcione aprendizagem ativa com metacognição, ideias defendidas ao longo de todo o trabalho. 
Lançando mão da reflexão linguística e das atividades de revisão e reescrita textual, usamo-las na tentativa de trabalhar a identificação do funcionamento da língua, a partir da análise de textos e das conclusões decorrentes da(s) simetria(s) apresentada(s).

O foco da atividade foi a compreensão a partir do texto, pois, pela revisão textual, para além das normas gramaticais, trabalham-se as habilidades de leitura e escrita, fugindo da memorização. Desta feita, a atividade teve como objetivos específicos (1) aprimoramento da leitura, da escrita e da oralidade; (2) identificação dos tipos de verbos (seleção argumental e transitividades verbais) para conscientização sintática.

Abaixo, seguem as etapas que constituem tal sequência ${ }^{14}$, os objetivos pretendidos e a ratificação dos conceitos nos quais se apóiam, já discutidos nos capítulos anteriores deste trabalho.

\section{Etapa:}

- Começar a aula debatendo sobre a criatividade linguística e suas manifestações, como nas gírias, na música, na poesia, na tecnologia (como em blogs, whatsapp etc.), entre outras. O objetivo da discussão é mostrar que, apesar da criatividade, seguimos uma regularidade nas línguas. A partir daí, o professor deve discutir sobre o tema da formação de sentenças e da escrita tendo como exemplos as experiências concretas dos alunos (escrita de um bilhete, de mensagem em redes sociais, de trabalhos escolares etc.). Terminada a discussão inicial, o professor deve passar para o poema como um exemplo de criatividade com regularidade.

A introdução com temas que envolvem o cotidiano do aluno visa a facilitar a aprendizagem, pela familiaridade com o conteúdo, e a aumentar a possibilidade do ensino com compreensão, porque, partindo do conhecimento inconsciente para trazer a consciência o que ainda não está claro, o aluno entende todo o processo de aprendizagem e se atenta para os mecanismos e estratégias cognitivas que usou no processo, gerando as informações bases que possibilitem a transferência do conteúdo adequada, quando necessária, e a aprendizagem com metacognição (VANPATTEN, 2003; BRANSFORD et al., 2007; PILATI, 2014; entre outros).

\footnotetext{
${ }^{14}$ A sequência didática completa com textos e tabelas é apresentada no Anexo II desta dissertação.
} 
Além disso, iniciar por um assunto que faça parte do contexto do aluno permite que seu conhecimento prévio seja levado em consideração, tanto para desmistificar falsas crenças e interpretações ingênuas ou incompletas (BRANSFORD et al., 2007), quanto para ser base para o novo conhecimento e trazer a consciência sintática (LOBATO, 2003; VICENTE \& PILATI, 2012; entre outros).

Há, ainda, o benefício de despertar o interesse do aluno sobre o assunto tratado e mostrar que a todo tempo os discentes estão em contato com a língua e que conseguem entendê-la e se comunicar por meio dela, quebrando o "tabu” de que a LP é difícil.

\section{$2^{\text {a }}$ Etapa:}

- Leitura dinâmica interpretativa do poema "De gramátida e de linguagem", de Mário Quintana. Escolhi esse poema para fazer uma breve discussão sobre a organização da oração, passando da classe de palavras, última matéria vista pela turma em que a sequência foi aplicada, para a construção de sentenças.

A leitura dinâmica interpretativa foi adotada para seguir uma prática comunicativas, ou seja, proporcionar interação em sala de aula e colocar a comunicação no centro das lições. Essa escolha torna a compreensão do significado o objetivo do currículo (VANPATTEN, 2003).

Outra intenção da leitura dinâmica foi envolver os alunos durante todo o processo de ensino-aprendizagem, mantendo a ideia do aluno como elemento ativo na aprendizagem (BRANSFORD et al., 2007; PILATI, 2014), além de trabalhar constantemente as habilidades de leitura e de fala e compreensão oral.

\section{$3^{\text {a }}$ Etapa:}

- Trabalhar com a primeira estrofe do poema, de forma conjunta com a turma, para realizar a atividade de reflexão linguística com ênfase na complementação verbal:

○ Colocar no quadro uma tabela dividida em "sujeito", "verbo", "complemento" e "adjunto" para preenchimento com a turma;

- Identificar os verbos;

- Trabalhar com as intuições dos alunos para perceberem as diferentes relações entre verbos e seus argumentos, começando pelo sujeito e seguindo para o(s) complemento(s) e o(s) adjunto(s); 
- Destacar, no quadro, os verbos de cada transitividade com cores diferentes para facilitar a assimilação dos alunos. Este último procedimento pode ser feito ao final desta etapa ou ao final da etapa 4, apresentada adiante, funcionando como uma revisão.

A análise intuitiva dos dados com reflexão linguística para identificação da regularidade da língua faz parte do procedimento de descoberta, em que o aluno, pela eliciação do professsor, toma consciência que já possui o conhecimento prévio necessário para compreender a língua e o utiliza. Como vimos, em Lobato (2003), uma consequência desse processo é a melhora do aluno em relação ao domínio de textos, pois, conhecendo e entendendo a estrutura de sua língua, ele pode manipulá-la para alcançar o resultado semântico que deseja. Ou seja, a consciência sintática leva a uma produção textual consciente que, agregada ao senso crítico, gera a autonomia do aluno.

Essa etapa também se baseia nas ideias de Pilati et al. (2011) quando buscam os dados a serem analisados na língua e, a partir daí, constroem as definições, já que, segundo as autoras, pela competência linguística, em geral, os estudantes conseguem distinguir as funções sintáticas e as relações gramaticais entre os verbos e seus complementos, sendo capazes de lidar intuitivamente com as questões gramaticais. Esse movimento contrário à instrução normativa é realizado, inicialmente, pela compreensão de textos e, em etapa posterior, pela produção textual.

Outra questão importante é o papel fundamental de mediador do qual o professor se encarrega nesse momento, uma vez que trabalha com as intuições que os estudantes têm acerca da própria língua, priorizando a reflexão como origem do ensino (VICENTE \& PILATI, 2012). Uma aula que segue esses pressupostos promove o entendimento do funcionamento da língua, assim, não é uma aula apenas de "como usá-la" (PILATI et al., 2011).

\section{$4^{\text {a }}$ Etapa:}

- Focar na relação do verbo com o(s) complemento(s) - direto, indireto ou sem complemento.

○ Colocar outra tabela no quadro dividida em "verbo", "complemento direto", "complemento indireto" e "classificação - transitividade verbal";

- Colocar os verbos identificados na etapa anterior na tabela e, ainda trabalhando com a intuição deles a partir da reflexão linguística, preencher as colunas com os complementos verbais; 
- Ao final, preencher a coluna da "classificação - transitividade verbal". Essa coluna só deve ser preenchida após todo o quadro estar completo, para que o aluno primeiro se conscientize do que sabe e, a partir daí, tenha acesso à nomenclatura da norma padrão. Assim, a relação entre o verbo e sua classificação será facilitada.

Esta etapa complementa a etapa 3 e, portanto, segue os mesmos princípios da referida etapa no que tange à análise intuitiva dos dados pela reflexão linguística.

A apresentação da nomenclatura normativa é a complementação do conhecimento, agora consciente, e é um exemplo de conteúdo que precisa ser aprendido de fato e não só tornado conhecimento explícito, visto que não é possível somente se tomar consciência dele. Essa parte se faz necessária para enriquecer a aprendizagem do aluno, munindo-o de conhecimento suficiente para poder lidar com as várias formas de exercícios e abordagens sobre o assunto com as quais ele pode se deparar ao longo da vida estudantil.

\section{5 atapa:}

- Pedir para que os alunos, em duplas ou trios, sigam o mesmo processo com os verbos da parte inicial da segunda estrofe do poema, fazendo uma tabela que destaque "sujeito", "verbo", "complemento", "adjunto" e "transitividade", ou seja, é a junção das tabelas das etapas 3 e 4;

- Corrigir e solicitar que os alunos, agora sozinhos, repitam a atividade na parte final da segunda estrofe do poema. Fazer a correção após tempo hábil para que os alunos realizem a atividade proposta.

Esta etapa reforça o conteúdo estudado de forma conjunta e individual, dando vários exemplos para o aluno e fazendo-o voltar a acessar o novo conhecimento. Esse processo ajuda na maior conscientização do conteúdo, que era inconsciente, na internalização do conteúdo aprendido (a classificação normativa) e na compreensão dos processos envolvidos para acessar o conhecimento sempre que necessário, tornando-o "conhecimento utilizável".

O trabalho em pequenos grupos e depois individualmente, tanto permite a constante transferência do conteúdo, quanto gera a confiança paulatina do aluno, dandoIhe autonomia no processo de aprendizagem e acarretando aprendizagem com metacognição (BRANSFORD et al., 2007; PILATI, 2014; entre outros). 


\section{$6^{\text {a }}$ Etapa:}

- Revisão final: estabelecer relações entre o conhecimento do aluno e as transitividades verbais do dia a dia

- Pedir exemplos de frases do dia a dia que contenham as transitividades verbais estudadas;

- Escrever as frases no quadro e analisá-las;

- Se não aparecerem, sugerir alguns exemplos com verbos que mudam a transitividade a depender do contexto para que os alunos percebam que não precisam memorizar a matéria, mas sim refletir sobre 0 funcionamento da língua, compreendendo-a. Deixar isso claro.

A revisão final com mais exemplos segue a lógica da etapa anterior de acomodação do conhecimento, fazendo o aluno realizar constantemente a transferência do conteúdo estudado (VANPATTEN, 2003; PILATI, 2014). Além disso, mantém a ideia do trabalho que leva em consideração a realidade do aluno, já que eles sugestionarão os exemplos dentro do que vivem no cotidiano, e do aluno como participante ativo do processo de ensino-aprendizagem.

O trabalho com os verbos que apresentam transitividades distintas, a depender do contexto comunicativo, aprofunda o assunto estudado, ampliando o conhecimento do discente e, como dito na descrição da etapa, deixando claro para o aluno que não há necessidade de decorar a matéria. Parte do conteúdo eles já sabem e o processo de aprendizagem o torna consciente. Outra parte é aprendida, assimilada e internalizada ao longo do processo com os vários exemplos e exercícios. O importante é partir da reflexão linguística para compreender o funcionamento da língua e para a identificação das variações que os diversos contextos comunicativos podem apresentar.

\section{$7^{\text {a }}$ Etapa:}

- Analisar um texto que apresenta irregularidades propositalmente inseridas. Pedir para que os alunos:

○ Revisem o texto, identificando as irregularidades;

- Proponham uma reescrita textual de forma a sanar os problemas identificados.

- Mostrar que os problemas de ortografia, referenciação e concordância verbal apresentados no texto são algumas das várias questões que temos que prestar atenção na escrita para não prejudicar a coesão e coerência textual. Focar a questão da concordância verbal que está diretamente ligada ao conteúdo da aula. 
Nesta etapa, tem-se a aplicação, de forma individualizada, do conhecimento adquirido, e do acumulado, por meio da revisão textual e da reescrita, dando ao aluno mais uma oportunidade para trabalhar a transferência do assunto e se autoavaliar sobre o entendimento satisfatório, ou não, de todo o processo de ensino-aprendizagem a partir da metacognição (PILATI, 2014).

\subsection{A aula tradicional}

A aula tradicional (cf. Anexo III) seguiu uma metodologia expositiva em que se expuseram os dados no quadro com exemplos, explicou-se cada termo e fizeram-se alguns exercícios exemplificativos.

\subsection{A atividade avaliativa}

A atividade avaliativa ${ }^{15}$ testou o conhecimento adquirido do aluno, o output que este fornece, seguindo a lógica da sequência didática e tendo textos como base para todo o processo de ensino-aprendizagem com o qual o aluno se deparou em sala de aula.

A questão 1 apresentou um pequeno parágrafo e solicitou que os termos da oração (sujeito, verbo, complementos e adjuntos), assim como a transitividade do verbo, fossem identificados.

A questão 2 apresentou um novo trecho com irregularidades propositais e pediu para, após seguir os mesmos passos da questão 1, o aluno identificar pelo menos dois aspectos problemáticos do texto.

A questão 3 solicitou a reescrita do texto da questão 2 com o objetivo de sanar os desvios gramaticais apresentados.

\subsubsection{Análise dos resultados}

Apurou-se o resultado contabilizando o número de acertos por cada item do exercício, ou seja, nas questões 1 e 2 levou-se em consideração a resposta de cada identificação dos termos da oração feita pelo aluno. A segunda parte da questão 2 e a

\footnotetext{
${ }^{15}$ A atividade completa pode ser vista no Anexo IV.
} 
questão três foram apuradas em conjunto, porque a maioria dos alunos mesclou as respostas, apontava o desvio na questão 2 e já apresentava a reescrita ou vice-versa.

Vejamos os resultados:

\section{- Questão 1}

O texto da questão 1 era composto por seis verbos que os alunos deveriam identificar, primeiramente, para seguir com a identificação dos outros termos da oração, daí a divisão da tabela a seguir com a contabilização do número de acertos em ordem decrescente, daqueles que acertaram todos os itens de cada termo até os que não responderam.

Turma CS

(ministrou-se a sequência didática)

\begin{tabular}{|l|c|c|c|c|c|c|c|c|}
\hline & $\begin{array}{c}\mathbf{6} \\
\text { acertos }\end{array}$ & $\begin{array}{c}\mathbf{5} \\
\text { acertos }\end{array}$ & $\begin{array}{c}\mathbf{4} \\
\text { acertos }\end{array}$ & $\begin{array}{c}\mathbf{3} \\
\text { acertos }\end{array}$ & $\begin{array}{c}\mathbf{2} \\
\text { acertos }\end{array}$ & $\begin{array}{c}\mathbf{1} \\
\text { acerto }\end{array}$ & $\begin{array}{c}\mathbf{0} \\
\text { acerto }\end{array}$ & $\begin{array}{c}\text { Não } \\
\text { fez }\end{array}$ \\
\hline SUJEITO & 14 & 7 & 2 & 1 & 1 & 0 & 0 & 0 \\
\hline VERBO & 14 & 7 & 3 & 0 & 1 & 0 & 0 & 0 \\
\hline COMPLEMENTO & 1 & 7 & 9 & 4 & 4 & 0 & 0 & 0 \\
\hline ADJUNTO & 0 & 3 & 6 & 4 & 6 & 2 & 2 & 2 \\
\hline $\begin{array}{l}\text { TRANSITIVIDADE } \\
\text { VERBAL }\end{array}$ & 1 & 8 & 6 & 4 & 0 & 2 & 3 & 1 \\
\hline
\end{tabular}

Turma TR

(ministrou-se aula tradicional)

\begin{tabular}{|l|c|c|c|c|c|c|c|c|}
\hline & $\begin{array}{c}\mathbf{6} \\
\text { acertos }\end{array}$ & $\begin{array}{c}\mathbf{5} \\
\text { acertos }\end{array}$ & $\begin{array}{c}\mathbf{4} \\
\text { acertos }\end{array}$ & $\begin{array}{c}\mathbf{3} \\
\text { acertos }\end{array}$ & $\begin{array}{c}\mathbf{2} \\
\text { acertos }\end{array}$ & $\begin{array}{c}\mathbf{1} \\
\text { acerto }\end{array}$ & $\begin{array}{c}\mathbf{0} \\
\text { acerto }\end{array}$ & $\begin{array}{c}\text { Não } \\
\text { fez }\end{array}$ \\
\hline SUJEITO & 1 & 6 & 12 & 6 & 0 & 0 & 0 & 0 \\
\hline VERBO & 12 & 11 & 2 & 0 & 0 & 0 & 0 & 0 \\
\hline COMPLEMENTO & 1 & 4 & 10 & 4 & 3 & 1 & 2 & 0 \\
\hline ADJUNTO & 0 & 0 & 1 & 1 & 3 & 0 & 18 & 2 \\
\hline $\begin{array}{l}\text { TRANSITIVIDADE } \\
\text { VERBAL }\end{array}$ & 3 & 2 & 1 & 6 & 5 & 3 & 4 & 1 \\
\hline
\end{tabular}

Comparando as tabelas, podemos destacar, numa primeira análise, que a Turma CS apresentou proporção de acertos no que tange à relação verbo-sujeito - a quantidade 
de alunos que apontou o verbo, em seus diferentes níveis de acertos, correlacionou adequadamente seu sujeito. Na Turma TR, essa proporção não é encontrada, há discrepância entre a identificação do verbo e seu respectivo sujeito.

Ainda em exame preliminar da tabela, podemos observar que a Turma CS apresenta maior número de acertos no que se refere a:

- seis acertos: em todos os termos da oração, exceto em "transitividade verbal". Em "adjunto", houve empate entre as turmas, havendo destaque, portanto, em três dos cinco itens;

- cinco acertos: em todos os termos da oração, exceto no "verbo", destacando-se em quatro itens;

- quatro acertos: em todos os termos da oração, exceto no "sujeito" e "complemento", apresentando destaque em três dos cinco itens, portanto;

- três acertos: apenas no item "adjunto". Houve empate em "verbo" e "complemento";

- dois acertos: em todos os termos da oração, exceto em "transitividade verbal"; - um acerto: apenas no item "adjunto". Em "sujeito" e "verbo" houve empate;

- zero acerto: em nenhum item, o que significa que a Turma TR teve mais alunos que não acertaram os itens, exceto em "sujeito" e "verbo", em que houve empate;

- não fez: houve empate em todos os cinco itens.

Estatisticamente, fizemos a média ponderada de acertos de cada item ("sujeito", "verbo", "complemento", "adjunto" e "transitividade verbal"), considerando o número de alunos para ponderação, chegando ao seguinte resultado:

\begin{tabular}{|l|c|c|}
\hline \multirow{2}{*}{ ITENS } & \multicolumn{2}{|c|}{ MÉDIA DE ACERTOS } \\
\cline { 2 - 3 } & TURMA CS & TURMA TR \\
\hline SUJEITO & 5,28 & 4,08 \\
\hline VERBO & 5,32 & 5,40 \\
\hline COMPLEMENTO & 3,88 & 5,56 \\
\hline ADJUNTO & 2,60 & 0,52 \\
\hline TRANSITIVIDADE VERBAL & 3,32 & 2,52 \\
\hline
\end{tabular}


Assim, constatamos que a Turma CS apresentou maior número de acertos nos itens "sujeito", "adjunto" e "transitividade verbal", mostrando resultado inferior à Turma TR no que se refere a "verbo" e a "complemento".

Numa visão geral, considerando os cinco itens ("sujeito", "verbo", "complemento", "adjunto" e "transitividade verbal") a serem identificados em seis frases, juntamente com a opção de o aluno não acertar nenhum item ou, até mesmo, não fazê-lo, temos quarenta itens avaliados, conforme tabela apresentada. Deste total, a Turma CS obteve destaque em dezessete itens, 42,5\%, e empatou em doze itens, $30 \%$. A Turma TR, por sua vez, apresentou resultado melhor em onze itens, 27,5\%.

Diante de todos os dados expostos, concluímos que, de modo geral, a Turma CS teve resultado melhor frente à Turma TR, uma vez que a maioria dos índices da turma que recebeu a sequência didática baseada em revisão textual e reescrita é superior ao da turma que assistiu à aula tradicional de gramática.

Sigamos para a próxima questão para aferir se esse resultado se mantém.

\section{- Questão 2}

Seguiu a mesma lógica de aferição da questão 1, com a diferença de que era composta por três verbos e foi feita individualmente pelos alunos. Temos como resultado:

\section{Turma CS}

\begin{tabular}{|l|c|c|c|c|c|}
\hline & $\begin{array}{c}3 \\
\text { acertos }\end{array}$ & $\begin{array}{c}\mathbf{2} \\
\text { acertos }\end{array}$ & $\begin{array}{c}\mathbf{1} \\
\text { acertos }\end{array}$ & $\begin{array}{c}\mathbf{0} \\
\text { acerto }\end{array}$ & $\begin{array}{c}\text { Não } \\
\text { fez }\end{array}$ \\
\hline SUJEITO & 13 & 3 & 8 & 0 & 1 \\
\hline VERBO & 15 & 3 & 6 & 0 & 1 \\
\hline COMPLEMENTO & 9 & 3 & 7 & 2 & 4 \\
\hline ADJUNTO & 5 & 3 & 7 & 5 & 5 \\
\hline $\begin{array}{l}\text { TRANSITIVIDADE } \\
\text { VERBAL }\end{array}$ & 0 & 8 & 6 & 7 & 4 \\
\hline
\end{tabular}


Turma TR

\begin{tabular}{|l|c|c|c|c|c|}
\hline & $\begin{array}{c}\mathbf{3} \\
\text { acertos }\end{array}$ & $\begin{array}{c}\mathbf{2} \\
\text { acertos }\end{array}$ & $\begin{array}{c}\mathbf{1} \\
\text { acertos }\end{array}$ & $\begin{array}{c}\mathbf{0} \\
\text { acerto }\end{array}$ & $\begin{array}{c}\text { Não } \\
\text { fez }\end{array}$ \\
\hline SUJEITO & 9 & 11 & 5 & 0 & 0 \\
\hline VERBO & 21 & 4 & 0 & 0 & 0 \\
\hline COMPLEMENTO & 12 & 6 & 4 & 3 & 0 \\
\hline ADJUNTO & 2 & 3 & 4 & 11 & 4 \\
\hline $\begin{array}{l}\text { TRANSITIVIDADE } \\
\text { VERBAL }\end{array}$ & 3 & 5 & 10 & 4 & 3 \\
\hline
\end{tabular}

Novamente, comparando as tabelas, destacamos, preliminarmente, a permanência da proporção de acertos relacionada ao verbo e ao sujeito apresentada pela Turma CS se contrapondo à discrepância encontrada na Turma TR.

Ainda em exame inicial da tabela, observamos que a Turma CS apresenta maior número de acertos no que se refere a:

- três acertos: nos itens "sujeito", "adjunto" e "transitividade verbal";

- dois acertos: apenas no item "transitividade verbal". Houve empate em "adjunto";

- um acerto: nos itens "sujeito", "verbo", "complemento" e "adjunto";

- zero acerto: em "transitividade verbal". Em "sujeito" e "verbo" houve empate;

- não fez: em todos os itens, ou seja, a Turma TR apresentou melhor resultado, nesse quesito, com menos alunos que deixaram de fazer o exercício.

Para análise estatística, fizemos a média ponderada de acertos de cada item ("sujeito", "verbo", “complemento", "adjunto" e "transitividade verbal"), considerando o número de alunos para ponderação, chegando ao seguinte resultado:

\begin{tabular}{|l|c|c|}
\hline \multirow{2}{*}{\multicolumn{1}{|c|}{ ITENS }} & \multicolumn{2}{|c|}{ MÉDIA DE ACERTOS } \\
\cline { 2 - 3 } & TURMA CS & TURMA TR \\
\hline SUJEITO & 2,12 & 2,16 \\
\hline VERBO & 2,28 & 2,84 \\
\hline COMPLEMENTO & 1,60 & 2,08 \\
\hline ADJUNTO & 1,0 & 0,64 \\
\hline TRANSITIVIDADE VERBAL & 0,88 & 1,16 \\
\hline
\end{tabular}


Observamos que a Turma CS apresentou maior número de acertos apenas no item "adjunto", com resultado inferior à Turma TR em todos os outros itens.

Numa visão geral, considerando os cinco itens ("sujeito", "verbo", "complemento", "adjunto" e "transitividade verbal") a serem identificados em três frases, juntamente com a opção de o aluno não acertar nenhum item ou, até mesmo, não fazê-lo, temos vinte e cinco itens avaliados, conforme tabela apresentada anteriormente. Deste total, a Turma CS obteve destaque em oito itens, 32\%, e empatou em dois itens, 8\%. A Turma TR, por sua vez, apresentou resultado melhor em quinze itens, 60\%.

Vê-se, portanto, que houve uma inversão do resultado apresentado na questão 1 , a Turma TR mostrou resultado superior à Turma CS.

Partamos, então para a próxima questão para ver qual tendência prevalece.

\section{- Segunda parte da Questão 2 e Questão 3}

A segunda parte da questão 2 solicitava a indicação de, no mínimo, dois aspectos problemáticos no trecho dado, e a questão 3 pedia sugestão de reescrita para adequação dos desvios encontrados na questão anterior. Como já dito, as respostas foram computadas em conjunto, porque a maioria dos alunos as mesclou, apontando o desvio na questão 2 e já apresentando sua reescrita ou vice-versa.

Cabe ressaltar que o texto da atividade apresentava três desvios propositais (dois de regência e um de acentuação), entretanto, houve um erro de digitalização que deixou duas palavras juntas e os alunos recorreram bastante a esse erro como resposta, indicando-o como uma irregularidade.

Seguem os resultados:

Turma CS

\begin{tabular}{|l|c|c|c|}
\hline & DUAS & UMA & NENHUMA \\
\hline Identificação de irregularidades & 8 & 10 & 7 \\
\hline Reescrita adequada & 7 & 8 & 10 \\
\hline
\end{tabular}

Turma TR

\begin{tabular}{|l|c|c|c|}
\hline & DUAS & UMA & NENHUMA \\
\hline Identificação de irregularidades & 10 & 15 & 0 \\
\hline Reescrita adequada & 10 & 9 & 6 \\
\hline
\end{tabular}

De acordo com as tabelas expostas, podemos ver que, numericamente, a Turma CS está em desvantagem com um número menor de respostas desejadas, entretanto é 
relevante indicar que (a) tanto na Turma CS quanto na Turma TR, os alunos que apontaram apenas uma irregularidade consideraram o erro de digitação, a falta de espaço entre as palavras como desvio; (b) dos oito alunos da Turma CS que assinalaram duas irregularidades, cinco deles não recorreram ao erro de digitação, apontando dois dos três desvios propositadamente colocados no texto. Já na Turma TR, dos dez alunos que indicaram duas irregularidades, todos consideraram o erro de digitação como uma delas, como uma falha textual. Desta feita, acreditamos que, qualitativamente, a Turma CS apresentou um desenvolvimento superior ao da Turma TR.

Sendo assim, temos que, das três partes da atividade avaliada, priorizando a avaliação qualitativa, a Turma CS se destacou em duas delas. Ousamos, portanto, concluir que a Turma CS manifestou resultado melhor, pois a questão 1 exibia número maior de frases que a questão 2 e, na última atividade, vimos que a Turma CS se destacou qualitativamente por se ater às irregularidades reais do texto, e não a um erro de digitação. Para colaborar com tal conclusão a próxima seção revela as impressões dos alunos quanto à sequência em teste e à aula tradicional, a partir da avaliação da proposta pedagógica.

\subsection{A avaliação da proposta pedagógica}

Por fim, a Avaliação da Proposta Pedagógica (cf. Anexo V) foi a última etapa do projeto piloto e buscou aferir a efetividade da sequência didática, aos olhos dos discentes, pela comparação das respostas da turma em que a sequência foi ministrada, com aquela onde houve a aula tradicional.

As perguntas buscaram investigar os objetivos da sequência didática, que eram:

- Ser apresentada de forma interessante;

- Contribuir com a aprendizagem do aluno;

- Respeitar o nível de cada aluno;

- Facilitar o entendimento; e

- Acrescentar conhecimento útil.

As respostas foram diretas, com as opções "SIM" ou "NÃO", para facilitar a participação de todos, uma vez que essa etapa foi feita ao final do processo e havia a possibilidade de os alunos estarem cansados, e também para viabilizar a aferição dos resultados com maior objetividade. 


\subsubsection{Análise dos resultados}

Chegaram-se aos seguintes resultados ao computar as respostas da Turma CS e da Turma TR sobre a avaliação da proposta pedagógica:

\begin{tabular}{|l|c|c|c|c|}
\hline \multicolumn{1}{|c|}{ PERGUNTAS } & \multicolumn{2}{|c|}{ TURMA CS } & \multicolumn{2}{c|}{ TURMA TR } \\
\cline { 2 - 5 } & SIM & NÃO & SIM & NÃO \\
\hline $\begin{array}{l}\text { 1. A atividade foi apresentada de forma interessante, } \\
\text { gerando motivação para aprender o assunto? }\end{array}$ & 25 & 0 & 18 & 7 \\
\hline $\begin{array}{l}\text { 2. A atividade tem um nível de dificuldade } \\
\text { condizente com seus conhecimentos? }\end{array}$ & 23 & 2 & 20 & 5 \\
\hline $\begin{array}{l}\text { 3. A atividade facilitou a aprendizagem do assunto? } \\
\text { você? }\end{array}$ & 17 & 8 & 17 & 8 \\
\hline $\begin{array}{l}\text { 5. A atividade acrescentou conhecimento útil para } \\
\text { forma? Qual? }\end{array}$ & 24 & 0 & 14 & 11 \\
\hline
\end{tabular}

Considerações:

- Um aluno da Turma CS não respondeu a questão 4 e outro não respondeu a questão 5.

- A resposta "talvez" foi acrescentada por aluno da Turma CS na questão 5.

Graficamente, essas distinções ficam assim representadas:

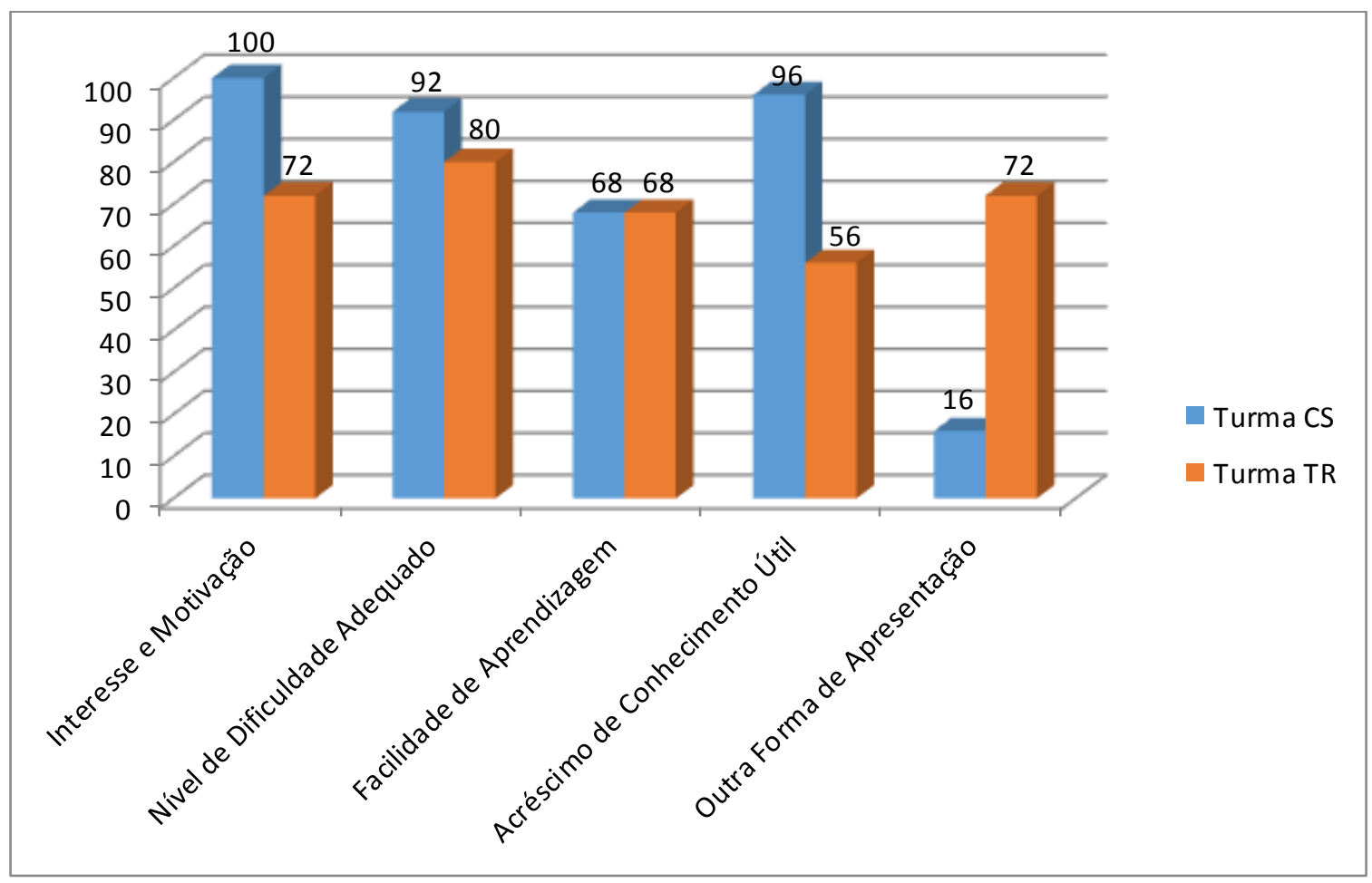


Vê-se claramente a distinção entre os resultados da avaliação da proposta pedagógica da Turma CS (sequência didática e atividade avaliativa) para a Turma TR (aula tradicional e atividade avaliativa). Todos os alunos (100\%) da Turma CS acharam a proposta pedagógica interessante e se sentiram motivados para estudar o conteúdo, Na Turma TR esse resultado foi de $72 \%$. Levando em consideração que a motivação é fator crucial para o desenvolvimento do aluno em sala de aula, esse resultado deve ser atentamente observado, pois pode representar uma mudança significativa do comportamento e dos resultados apresentados pelos discentes. O interesse e a motivação facilitam a aprendizagem para o aluno e o ensino para o professor, por tornarem as aulas mais agradáveis para ambos, numa troca constante de conhecimento com dedicação e prazer.

Quanto ao nível de dificuldade, 92\% da Turma CS acharam que a atividade tem um nível de dificuldade de acordo com seus conhecimentos, ou seja, não há excesso de cobrança sobre o conteúdo apresentado nem fuga do tema e dos assuntos abordados. Na Turma TR esse valor foi de $80 \%$. Apesar de a Turma CS não ter alcançado grande destaque frente à Turma TR nesse quesito, ainda assim, houve resultado positivo e pode-se concluir que o trabalho de reflexão linguística baseado na revisão e reescrita de textos não é inferior em conteúdo nem em expressão, quando comparado com as atividades tradicionais de gramática, não podendo, portanto, ser considerado mais "fraco" nem menos eficaz.

Surpreendentemente, houve empate quanto à facilidade de aprendizagem do conteúdo, 68\% dos alunos acharam que a atividade facilitou a assimilação do assunto. Esse poderia ser um ponto que colocaria em cheque toda a pesquisa, mas é preciso atentar que tal resultado (1) mostra, como na pergunta anterior, semelhanças entre as atividades, a testada e a tradicional, revelando que a nova proposta não é inferior às tradicionais existentes, (2) a pergunta subsequente mostra que, aquém deste empate, há evidente disparidade quanto ao conhecimento agregado: $96 \%$ da Turma CS sentiu que a atividade acrescentou conhecimento útil para sua vida, enquanto apenas 56\% da Turma TR teve a mesma percepção. Para a escola, não há papel maior que agregar conhecimento para o aluno de modo a formar um cidadão para o mundo. Desta feita, esse resultado, sem dúvida, eleva a efetividade da proposta testada.

Por fim, seguindo o curso esperado, apenas $16 \%$ da Turma CS disse que a atividade poderia ser realizada de outra forma. Na Turma TR, por outro lado, esse número é de $72 \%$, ou seja, um número significativo de alunos prefere abordagem 
diferente da utilizada. Mais uma vez, a proposta apresentada se destaca frente à atividade tradicional e pode-se concluir que a atividade que gera reflexão promove uma aprendizagem mais eficaz que aquela que se baseia na memorização.

Sobre os comentários e/ou sugestões, cabe ressaltar a diferença de comentários entre as turmas. Fica clara a dificuldade maior que a Turma TR teve para fazer a atividade e, apesar disso, alguns alunos ainda fizeram questão de deixar registrado que a atividade proposta era "muito boa" e "legal" de se fazer. Ou seja, mesmo a turma que recebeu a aula tradicional, apesar das dificuldades, sentiu simpatia pela atividade proposta, mostrando satisfação em fazer uma atividade baseada em textos.

\subsection{Considerações do capítulo}

Ressaltam-se os bons resultados que o projeto alcançou. Nas questões 1 e 3, a turma que passou por todas as etapas do projeto piloto (sequência didática e atividade avaliativa) destacou-se, o que ratifica toda a discussão da importância do "ensino" ativo de gramática, primando pela reflexão e conscientização do saber que o aluno já possui e utilizando textos, tanto no trabalho com revisão quanto com reescrita, para esse fim. Esse resultado também confirma a necessidade de incluir, em contexto educacional, a situação comunicativa no trabalho com a gramática da língua escrita.

Houve destaque também na avaliação da proposta metodológica, o projeto instigou o interesse dos alunos e conduziu à percepção de maior conhecimento útil, isso porque os alunos aprendem durante a reflexão.

Partindo da metodologia da descoberta, da técnica da eliciação, da aprendizagem ativa e de todos os outros conceitos que abordamos, construímos uma atividade aparentemente simples, mas que causou um impacto positivo no processo de ensinoaprendizagem dos envolvidos, comparada às metodologias utilizadas tradicionalmente.

Assim, acreditamos que o projeto piloto proposto tenha alcançado um resultado satisfatório para a pesquisa, levando em consideração, claro, que é um teste, um esboço e, por isso, precisa ser aprimorado a partir do aprofundamento constante dos estudos e, consequentemente, aperfeiçoamento da proposta com avaliação contínua dos resultados. Sem dúvida, é preciso submetê-lo a mais turmas e é necessária a utilização de mais textos, fato que foi inviabilizado pela indisponibilidade da turma devido à escassez de tempo do ano letivo. Essa tarefa fica para pesquisa futura. 


\section{Considerações Finais}

A presente pesquisa teve o objetivo de apurar, à luz dos pressupostos gerativistas e de metodologia baseada na aprendizagem ativa, estudos e propostas relativas à reflexão linguística e à revisão e reescrita textual como formas de promover a consciência sintática nas aulas de gramática. Buscou-se contribuir com a reflexão sobre uma possível saída do estudo de gramática meramente classificatório. Para isso, reuniram-se e analisaram-se trabalhos prévios sobre educação linguística que envolviam a reflexão e a revisão e reescrita textual. Houve, ainda, a proposta de projeto piloto que sugeriu uma sequência didática baseada nos estudos expostos.

No capítulo 1, passamos pelos pressupostos gerativistas de Chomsky, com os conceitos basilares da teoria gerativa de Faculdade da Linguagem, Gramática Universal, Input, Gramática Internalizada (Língua-I), Competência Linguística, Criatividade e Desempenho. Seguimos com Kato (2005) e sua comparação da aprendizagem da "gramática" da escrita no Brasil com a aquisição de uma segunda língua (L2) pela diferença apresentada entre a escrita e a fala, estando a fala na esfera da gramática nuclear, e a modalidade escrita na periferia marcada. Após, viu-se VanPatten (2003), que discute a importância dos processos de aquisição de segunda língua e cujas principais contribuições para este trabalho são: a defesa da aquisição envolver a criação de um conhecimento implícito inconsciente, mesmo que se tenha tido um aprendizado de regras explícitas através da aprendizagem formal em sala de aula, a importância de um input estruturado para isso, e o foco da aquisição estar no contexto comunicativo.

Ainda no mesmo capítulo, expomos sugestões metodológicas propostas por Lobato (2003), que consiste no procedimento de descoberta, na metodologia da eliciação e na técnica de resultados; por Vicente \& Pilati (2012), que defendem o "ensino" de gramática baseado no conhecimento linguístico prévio (gramática internalizada) concordando com o procedimento de descoberta de Lobato (2003) e com a eliciação, mas vendo esta última como uma técnica; e por Pilati et al. (2011), que defendem a abordagem da educação linguística, propondo uma metodologia de formulação de hipóteses e raciocínio inferencial dos dados linguísticos. Todo esse arcabouço foi discutido com o objetivo de evidenciar a necessidade de novas práticas 
docentes e o potencial que os conceitos gerativistas têm de atender a essa necessidade, por trazerem um novo olhar sobre o "ensino" de gramática.

O capítulo 2 apresentou estudo sobre processos de aprendizagem, de Bransford et al. (2007), complementado pelo trabalho de Pilati (2014), que se baseia numa abordagem de aprendizagem ativa, defende o conhecimento prévio do aluno, corrobora a discussão sobre a importância do input e a diferença da gramática da fala e da escrita e defende o contexto comunicativo como foco da aquisição. Houve, ainda, a análise dos trabalhos de Silva (2015) e de Pilati, Sandoval e Zandomênico (2016), que elaboraram atividades baseadas nos pressupostos estudados. Elas colocaram em prática as discussões do capítulo 1 e evidenciaram a constância dos estudos gerativistas na área do ensino e a participação da revisão e da reescrita textual até esta etapa.

No capítulo 3, elaboramos um projeto piloto, composto por sequência didática, atividade avaliativa e avaliação da proposta metodológica, considerando a revisão e reescrita textual como técnica de ensino, uma vez que são usadas em sala de aula, na prática docente. No geral, o projeto apresentou resultados satisfatórios e, se não taxativos, por serem testes preliminares, mostrou que o trabalho com situações comunicativas, com reflexão sintática de textos em sala de aula, tem futuro promissor. Podemos afirmar isso tanto pela análise dos resultados das atividades aplicadas em sala, quanto pela opinião dos próprios alunos, quando da avaliação da proposta metodológica. Cabe ressaltar, novamente, que o projeto é apenas um piloto, isto é, um teste inicial que precisa ser aprofundado e submetido a mais turmas com o uso de mais textos para aperfeiçoamento e aferição concreta da eficácia em sala de aula.

A sugestão da sequência didática foi resultado (1) da busca por novas práticas que revitalizem e melhorem a qualidade do ensino e (2) da tentativa de sistematizar uma prática pedagógica que amenize a lacuna existente entre os estudos teóricos sobre linguagem e os materiais didáticos disponíveis que orientem a prática pedagógica. Partindo de uma metodologia que usa o conhecimento prévio, a reflexão linguística e a compreensão, podemos nos deparar com uma possibilidade de "ensino" de gramática que refulta o ensino meramente classificatório e se baseia no contexto comunicativo, atraindo o interesse do aluno e trazendo à consciência seu conhecimento internalizado, tornando-o explícito e útil, para então agregar novos conhecimentos e internalizá-los. Nesse sentido, concluimos que a reflexão linguística é crucial para as aulas de gramática e que as atividades de revisão e reescrita textual são ferramentas válidas e possíveis de serem utilizadas para a promoção da consciência sintática. 
A consciência sintática, por sua vez, permite ao aluno entender seu sistema linguístico (princípios, regras e funcionamento da língua), levando-o a uma produção textual mais consciente. Essa produção é, inclusive, um fator que relaciona diretamente à pratica comunicativa e sociolinguística dos PCNs ao "ensino" de gramática. A grande importância deste trabalho e do estudo de gramática de forma geral está, então, no resultado gerado pela consciência linguística, pois uma produção textual consciente alinhada a um senso crítico desenvolvido produz autonomia, que é o objetivo fim da educação.

Assim, após essa longa jornada e tantos conceitos expostos e discutidos, chegamos ao final deste trabalho. Ainda há questões abertas que precisam ser analisadas e/ou refinadas, como já foi dito sobre o projeto piloto que precisa de aperfeiçamento, mas esta tarefa ficará a cargo de pesquisas futuras que disponham de mais tempo. À vista disso, resta-nos a esperança de que esta pesquisa coopere para o avanço dos estudos gerativistas ligados ao ensino. Destarte, alcançamos o ponto final, mas não o fim da caminhada, que está só começando. Alguns passos importantes já foram dados e muitos outros ainda serão, é só questão de tempo. 


\section{Referências Bibliográficas}

BRASIL. Secretaria de Educação Fundamental. Parâmetros curriculares nacionais: língua portuguesa. Brasilia. 1997a.

Secretaria de Educação Fundamental. Parâmetros curriculares nacionais: introdução aos parâmetros curriculares nacionais. Brasília. 1997b.

BRANDÃO, Ana Carolina P. A revisão textual na sala de aula: reflexões e possibilidades de ensino. In: LEAL, Telma F.; BRANDÃO, Ana Carolina P. (Orgs.). Produção de textos na escola: reflexões e práticas no Ensino Fundamental. Belo Horizonte : Autêntica, 2007, cap 7, p.119-134.

CHOMSKY, Noam. Aspectos da teoria da sintaxe. Coimbra: Arménio Amado, 1965. (Tradução de JoséAntônio Meireles e Eduardo Paiva Raposo, 1978).

. et al. Novas perspectivas linguísticas. Petrópolis: Vozes, 1970.

Reflexões sobre a linguagem. São Paulo: Cultrix, 1980.

Zahar, 1981.

Regras e representações: a inteligência humana e seu produto. Rio de Janeiro:

Linguagem e mente: pensamentos atuais sobre antigos problemas. Brasília: Editora da UnB, 1998.

. Sobre natureza e linguagem. BELLETTI, Adriana e RIZZI, Luigi (Orgs.). São Paulo: Martins Fontes, 2006.

COMITÊ DE DESENVOLVIMENTO DA CIÊNCIA E DA APRENDIZAGEM. Como as pessoas Aprendem: cérebro, mente, experiências e escola. Edição Brasileira: São Paulo: Senac, 2007.

COSTA, et al. Conhecimento Linguístico Explícito. Guião de implementação do programa. Lisboa, 2010.

FRANCHI, Carlos. Criatividade e gramática. In: C. Franchi; E. V. Negrão; A L. Müller. (Organização de S. Possenti). Mas o que é mesmo "Gramática”? São Paulo: Parábola, 2006. 
INSTITUTO NACIONAL DE ESTUDOS E PESQUISAS EDUCACIONAIS ANÍSIO TEIXEIRA (INEP). IDEB - Resultados e Metas. Disponível em:<http:/ideb.inep.gov.br/resultado/resultado/resultadoBrasil.seam?cid=12947522>.

Acessado em 22 mai 2015.

INSTITUTO NACIONAL DE ESTUDOS E PESQUISAS EDUCACIONAIS ANÍSIO TEIXEIRA (INEP). O que é o Ideb. Disponível em: <http//portal.inep.gov.br/web/portal-ideb/o-que-e-o-ideb>. Acessado em 22 mai 2015.

KATO, Mary A. A Gramática do Letrado: Questões para a Teoria Gramatical. Ciências da Linguagem: trinta anos de investigação e ensino. Braga, CEHUM (U. do Minho), 2005, p.131-145.

LOBATO, Lúcia. O que o professor de ensino básico deve saber sobre linguística? Fortaleza: SBPC, 2003.

NEVES, Maria Helena M. Gramática na escola. $3^{\text {a }}$ ed. São Paulo: Contexto, 1994.

PILATI, Eloisa. "Laboratório de Ensino de Gramática: Questões, Desafios e Perspectivas". In: VIEIRA, J. A.; SILVA, F. C. O. da. (Orgs.). O que a distância revela: reflexões de professores e estudantes do Curso de Letras - EaD-UnB. Brasília: Movimento, p. 48 - 67, 2014.

; NAVES, Rozana R.; VICENTE, Helena G.; SALLES, Heloisa. "Educação linguística e ensino de gramática na educação básica". In. Linguagem \& Ensino, v.14, n.2, p.395-425, jul./dez. 2011.

; VICENTE, Helena G. Teoria Gerativa e "ensino" de gramática: uma releitura dos Parâmetros Curriculares Nacionais. In: Verbum - Cadernos de Pós-Graduação, São Paulo, n. 2, p. 4-14, jul./dez. 2012.

; SANDOVAL, Alzira N.; ZANDOMÊNICO, Stefania C. M. de R. Práticas inovadoras para a sala de aula de gramática. No prelo, 2016.

SILVA, Juliana C. A. C. L. da. Estudo de caso sobre o desenvolvimento da consciência sintática em sala de aula. 2015. 94 f. Dissertação (Mestrado em Linguística). Instituto de Letras, Universidade de Brasilia, Brasilia, 2015.

SILVA, Junia L. da. Contribuições dos pressupostos gerativistas para a educação em língua materna. 2013. 88 f. Dissertação (Mestrado em Linguística). Instituto de Letras, Universidade de Brasília, Brasilia, 2013.

UOL

Educação.

Disponível

em:

$<$ http//educacao.uol.com.br/noticias/2013/03/14/brasil-tem-3-maior-taxa-de-evasaoescolar-entre-100-paises-diz-pnud.htm>. Acessado em: 22 mai 2015.

VANPATTEN, Bill. From input to output: a teacher's guide to second language acquisition. United States of America, 2003. 


\section{Anexo I}

\section{Atividade proposta por Silva (2015)}

\section{Sujeito e Predicado}

Primeira etapa - Que tipo de elemento pode ocupar a função de sujeito ${ }^{2}$ ?

Observe a forma verbal a seguir:

\section{ANUNCIARAM}

1. Quais dos elementos a seguir poderiam ter praticado a ação expressa pela forma verbal em questão? Circule-os.
As cadeiras
Os jornais
O jovem
Os funcionários
A menina

2. Por que os termos "O jovem" e "A menina" não poderiam ter praticado a ação?

3. Por que o termo "Os jornais" poderia ser sujeito da ação expressa pelo verbo, mas o termo "As cadeiras" não o poderia se ambos se tratam de objeto inanimados?

4. Por que os termos "Os jornais" e "Os funcionários" poderiam ser sujeitos de tal verbo? O que eles apresentam que as opções "O jovem" e "A menina" não possuem? 
Obs.: Como você observou na questão 4 , os termos $O$ jovem e $A$ menina, apesar de poderem praticar a ação expressa pelo verbo não poderiam exercer a função de sujeito, uma vez que o verbo está no plural e os termos em questão se encontram no singular ${ }^{3}$.

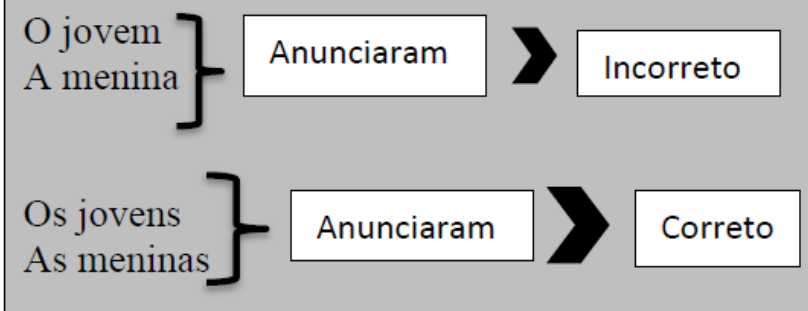

Esse tipo de relação, que se estabelece entre o sujeito e o verbo, na qual ambos devem estar no plural ou ambos devem estar no singular, é o que chamamos de concordância. Ou seja, o sujeito e o verbo devem concordar em número (singular ou plural).

Como você pôde ver, temos dois critérios para relacionar o sujeito ao verbo: um critério semântico e um critério sintático.

- Critério Semântico - diz respeito à possibilidade de que o sujeito pratique ação expressa pelo verbo. Não se trata de um critério fixo, pois dependerá do contexto em que se encontra a oração.

- Critério Sintático - é o que se refere às relações de concordância, no qual o sujeito e o verbo deem concordar em relação ao número (singular ou plural)

Diante do que foi exposto e a partir da análise do verbo CANTARAM, circule, na lista abaixo, os termos que não podem ser sujeito de tal verbo por violarem o critério semântico e sublinhe os que não podem ser sujeito por violarem o critério sintático.
As pipas
O passarinho
A professora
As lâmpadas

Agora assinale a única alternativa correta na questão abaixo.

O que observamos a princípio é que a posição do sujeito pode ser ocupada por:

A) Qualquer tipo de elemento independente das relações de concordância

B) Elementos animados e inanimados independente das relações semânticas

C) Qualquer tipo de elemento desde que haja concordância

D) Elementos animados e inanimados desde que concordem com o verbo e obedeçam ao critério semântico. 
1. Relacione os elementos da coluna $\mathrm{A}$ às afirmações presentes na coluna $\mathrm{B}$ de maneira coerente.

Coluna A

Maria

João

A cadeira

As crianças

O bebê

Os livros

As pesquisas
Coluna B

caíram da mesa

chegou cedo do trabalho

é bonita

quebrou

mostraram novos dados

precisam brincar

chora

2. Algum dos elementos presentes na coluna A poderia ser relacionado a mais de um elemento da coluna B? Caso isso ocorra, indique o elemento e as possíveis combinações. Caso isso não possa ocorrer, justifique.

3. A que elemento você relacionou o termo "A cadeira"? Justifique.

4. O termo "A cadeira" poderia ser relacionado ao elemento "chegou cedo do trabalho". Por quê?

5. O termo "O bebê" poderia ser relacionado ao elemento "caíram da mesa". Por quê?

6. O que você observou nos elementos da coluna A e B Ao relacioná-los?

Na questão abaixo, assinale a única alternativa correta.

Nessa etapa observamos que sujeito se relaciona ao verbo:

A) Apenas por questões semânticas (de sentido lógico)

B) Por questões semânticas (de sentido lógico) e sintáticas (de concordância)

C) Apenas sintáticas (de concordância)

D) Não há nenhum critério específico para relacionar o sujeito ao verbo 
Terceira etapa - Identificando os tipos de sujeito

Observe as orações abaixo e circule os verbos nelas presentes:

a) Maria come muito.

b) Chove forte no sul do país.

c) Os dados revelam o inesperado.

d) Roubaram o meu celular.

e) O cálculo e a resposta são contraditórios.

f) Vi você no ônibus.

1. A cada um dos verbos circulados faça a pergunta "QUEM?", antes do verbo e escreva abaixo as respostas obtidas.

a)

b)

c)

d)

e)

f)

2. As respostas obtidas em 1 correspondem àquilo que nós identificamos como "sujeito". Pensando nessa afirmação, responda:

a) Alguma das orações analisadas não apresenta resposta para a pergunta "QUEM?"? Quais são elas e o que elas indicam?

b) Alguma das orações analisadas apresenta uma resposta à pergunta "QUEM?" sem, no entanto, essa resposta estar expressa na oração?

Assinale a única alternativa correta.

Até agora verificamos que:

A) Apenas elementos animados podem responder a pergunta "QUEM?"

B) Quando o elemento que serve de resposta à pergunta "QUEM?" não está expresso na oração, é um sinal de que a oração não tem sujeito

C) Tanto elementos animados, quanto elementos inanimados podem responder a pergunta “QUEM?", sendo que estes podem, ou não, estar expressos na oração.

D) Quando o sujeito não está expresso na oração ele não pode ser identificado.

c) Divida as orações no quadro abaixo de acordo com a possibilidade, ou não, de se circular o sujeito na oração, ou seja, com o fato de eles estarem expressos ou não. 


\begin{tabular}{|l|l|}
\hline Sujeitos expressos & Sujeitos não-expressos \\
\hline & \\
\hline & \\
\hline & \\
\hline & \\
\hline & \\
\hline
\end{tabular}

d) Com base no que foi respondido nas questões anteriores, é possível afirmar que não é possível identificar os sujeitos quando estes não estão expressos? Justifique.

e) Agora distribua as orações seguintes no quadro abaixo de acordo com a forma com que o sujeito se apresenta na oração: expresso, não-expresso identificável, não-expresso e não-identificável.

I. Índices de desempenho alarmam os educadores.

II. O material da escola ficou em cima da mesa.

III. Vou ao shopping à tarde.

IV. Trovejou durante à noite.

V. Celulares e aparelhos eletrônicos permanecem desligados.

VI. Falaram de você na reunião.

VII. A criança come muito.

VIII. Brincamos com os vizinhos.

IX. A caneta e o lápis sumiram.

$\mathrm{X}$. Faz três meses desde a reforma.

$\mathrm{XI}$. O que faltou na festa?

XII. Eles disseram a verdade.

\begin{tabular}{|l|l|l|}
\hline Sujeito expresso & $\begin{array}{c}\text { Sujeito não-expresso } \\
\text { identificável } \\
\text { (Sujeito Desinencial) }\end{array}$ & $\begin{array}{c}\text { Sujeito não-expresso e } \\
\text { não-identificável } \\
\text { (Sujeito Inexistente) }\end{array}$ \\
\hline & & \\
\hline & & \\
\hline & & \\
\hline & & \\
\hline & & \\
\hline & & \\
\hline
\end{tabular}


f) No que diz respeito às frases que preenchem a coluna do "sujeito expresso", em quais delas mais de um substantivo responde a pergunta "QUEM?"?

g) Agora divida as orações que responderam ao item $\mathbf{f}$ em duas colunas: as que apresentam apenas um substantivo à pergunta "QUEM?" (que comumente classificamos como sujeito simples) e as que apresentam mais de um substantivo como resposta à pergunta "QUEM?" (classificado como sujeito composto). ${ }^{5}$

\begin{tabular}{|c|c|}
\hline Sujeito Simples & Sujeito Composto \\
\hline & \\
\hline & \\
\hline & \\
\hline
\end{tabular}

Assinalando a única alternativa correta, responda.

Nessa etapa nós verificamos que:

A) Os sujeitos se distinguem em: animados e inanimados

B) O sujeito se distingue em apenas dois tipos: existente e inexistente

C) Há apenas dois tipos de sujeito: simples e compostos

D) Os sujeitos se distinguem em: existentes e inexistente, sendo que, quando há sujeito na oração, este pode ser: simples, composto ou desinencial

Ao todo, podemos classificar o sujeito em quantos tipos?

Além de substantivos, que outra classe de palavra também pode ocupar a posição de sujeito? 
Quarta etapa - relação entre o sujeito e o verbo

1. Observe a frase abaixo:

A garota disse que não vai viajar.

a) Quem é o sujeito da forma verbal em destaque?

Agora observe:

Que não vai viajar, disse a garota.

b) Os elementos da oração ou a relação semântica entre eles foram alterados? O que se alterou de fato no período?

c) Sendo assim, qual é o sujeito do verbo em destaque?

Observe novamente:

Era noite quando os homens chegaram.

d) Qual elemento é o sujeito do verbo em destaque?

e) É possível afirmar que o sujeito das orações é sempre o elemento que as iniciam? Por quê?

Continue observando:

Que você seja feliz é o que desejo.

f) Que estrutura corresponde ao sujeito do verbo em destaque?

g) O sujeito identificado corresponde a um substantivo ou a uma oração?

h) Pode-se afirmar que o sujeito será sempre uma palavra com valor substantivo? Por quê? 
Assinale a única alternativa correta.

Nessa etapa podemos observar que:

A) O sujeito é sempre o primeiro termo da oração;

B) O sujeito nem sempre é o primeiro elemento da oração, além de, também, poder ser expresso por uma oração (sujeito oracional);

C) Apenas substantivos podem ocupar a posição de sujeito;

D) O sujeito só é o primeiro elemento da oração quando está expresso por uma oração (sujeito oracional).

Quinta etapa - Você o revisor.

1. Identifique os sujeitos das formas verbais destacadas no parágrafo abaixo.

"A viagem não acaba nunca. Só os viajantes acabam. E mesmo estes podem prolongar-se em memória, em lembrança, em narrativa. Quando o visitante sentou na areia da praia e disse:

'Não há mais o que ver", saiba que não era assim. O fim de uma viagem é apenas o começo de outra. É preciso ver o que não foi visto, ver outra vez o que se viu já, ver na primavera o que se vira no verão, ver de dia o que se viu de noite, com o sol onde primeiramente a chuva caía, ver a seara verde, o fruto maduro, a pedra que mudou de lugar, a sombra que aqui não estava. É preciso voltar aos passos que foram dados, para repetir e para traçar caminhos novos ao lado deles. É preciso recomeçar a viagem. Sempre."”

Acaba -

Acabam -

Podem -

Sentou -

Disse -

É -

Caía -

Mudou -

É -

2. Agora identifique os sujeitos dos verbos destacados no parágrafo abaixo e reescrevao corrigindo os problemas referentes à concordância entre o verbo e o sujeito.

"Na ânsia por querer conquistar certas coisas na vida - casa própria, carro, um bom emprego-, as pessoas esquecem de viver e só se dá conta disso quando já têm tudo que precisa menos aquele sonho antigo. Aí elas se acham velhas demais para realizar e morre sem nem tentar, um pouco frustradas pela vida ter passado tão depressa. Uma vida assim está longe de ser ruim, mas acho que todos nasce para ter uma experiência extraordinária aqui, viver do seu jeito e deixar a sua contribuição. Chris Guillebeau é um desses caras que podemos ter inveja da vida que leva, ele já conhecem todos os 193 países do mundo e trabalha como escritor provocando as pessoas a fazerem o mesmo: o que quer que você tenha vontade. O dele era viajar, qual é o seu?" 
Sexta etapa - Sistematizando o que foi aprendido

Preencha as lacunas do esquema abaixo de maneira a relacionar corretamente as informações.

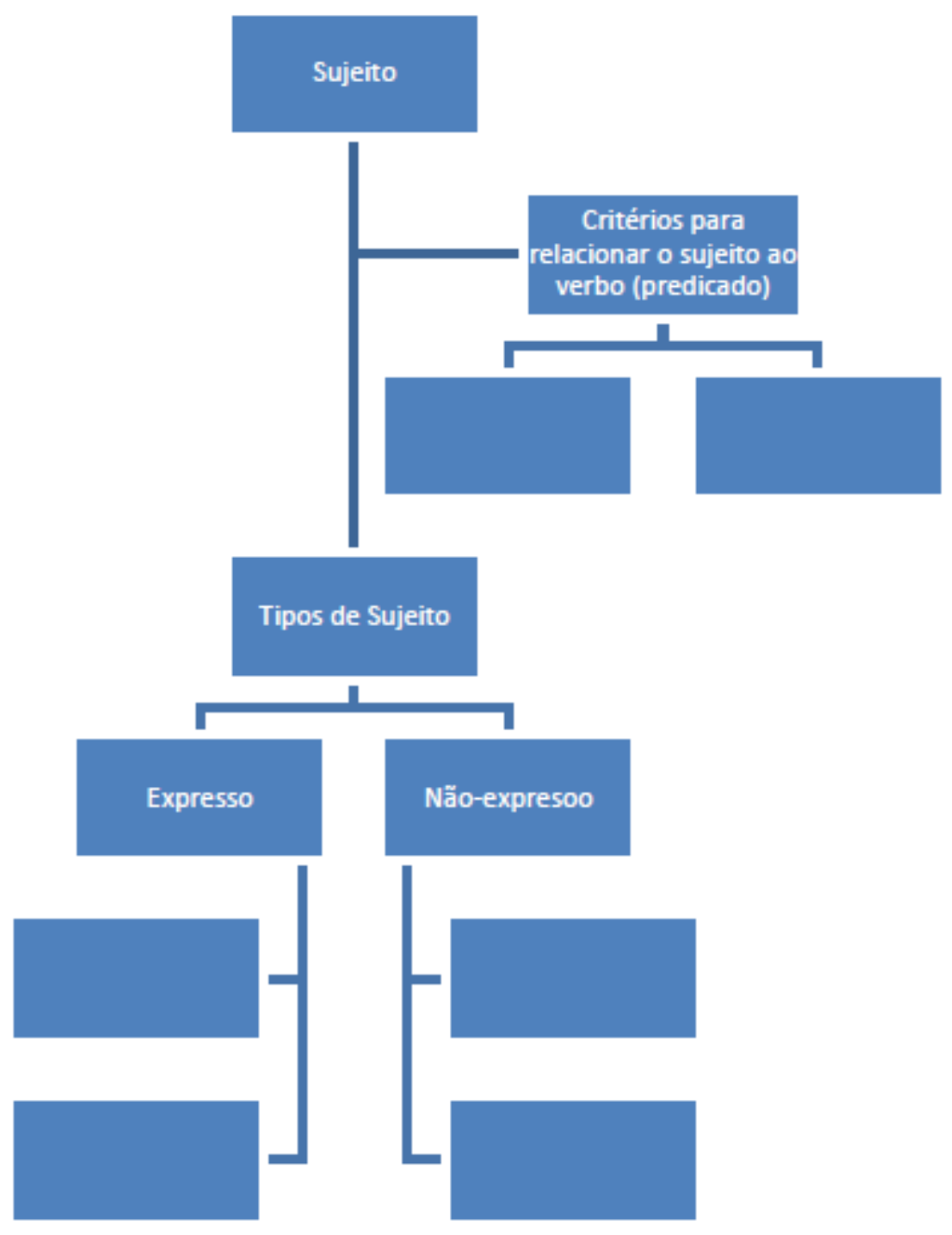




\section{Anexo II}

\section{PROPOSTA DE SEQUÊNCIA DIDÁTICA}

- Ano: $3^{\circ}$ do Ensino Médio.

- Gênero-base: Poema e texto referencial.

- Textos: De Gramática e de Linguagem, de Mário Quintana, e um texto referencial.

- Tempo de duração: 4 horas-aula

- Objetivos específicos:

- Aprimorar a leitura, a escrita e a oralidade;

- Identificar as transitividades verbais (seleção argumental) para conscientização sintática.

- Objetivo final: resposta a exercícios com atividades de revisão e reescrita textual de modo a demonstrar o avanço da consciência sintática.

TEXTO I:

\section{DE GRAMÁTICA E DE LINGUAGEM ${ }^{16}$ \\ Mário Quintana}

E havia uma gramática que dizia assim:

"Substantivo (concreto) é tudo quanto indica

Pessoa, animal ou coisa: João, sabiá, caneta".

Eu gosto das coisas. As coisas sim!...

As pessoas atrapalham. Estão em toda parte. Multiplicam-se em excesso.

As coisas são quietas. Bastam-se. Não se metem com ninguém.

Uma pedra. Um armário. Um ovo, nem sempre,

Ovo pode estar choco: é inquietante...)

As coisas vivem metidas com as suas cousas.

E não exigem nada.

Apenas que não as tirem do lugar onde estão.

E João pode neste mesmo instante vir bater à nossa porta.

Para quê? Não importa: João vem!

E há de estar triste ou alegre, reticente ou falastrão,

Amigo ou adverso...João só será definitivo

Quando esticar a canela. Morre, João...

\footnotetext{
${ }^{16}$ QUINTANA, Mario. Apontamentos de História Sobrenatural.6a ed. São Paulo: Globo, 1998.
} 
Mas o bom mesmo, são os adjetivos,

Os puros adjetivos isentos de qualquer objeto.

Verde. Macio. Áspero. Rente. Escuro. luminoso.

Sonoro. Lento. Eu sonho

Com uma linguagem composta unicamente de adjetivos

Como decerto é a linguagem das plantas e dos animais.

Ainda mais:

Eu sonho com um poema

Cujas palavras sumarentas escorram

Como a polpa de um fruto maduro em tua boca,

Um poema que te mate de amor

Antes mesmo que tu saibas o misterioso sentido:

Basta provares o seu gosto...

\section{PROPOSTA:}

\section{1 atapa:}

- Começar a aula debatendo sobre a criatividade linguística e suas manifestações, como nas gírias, na música, na poesia, na tecnologia (como em blogs, whatsapp, etc), entre outras. O objetivo da discussão é mostrar que, apesar da criatividade, seguimos uma regularidade nas línguas. A partir daí, o professor deve discutir sobre o tema da formação de sentenças e da escrita tendo como exemplos as experiências concretas dos alunos (escrita de um bilhete, de mensagem em redes sociais, de trabalhos escolares, etc). Terminada a discussão inicial, o professor deve passar para o poema (Texto I) como um exemplo de criatividade com regularidade.

\section{$2^{\text {a }}$ Etapa:}

- Leitura dinâmica interpretativa do poema "De gramática e de linguagem", de Mário Quintana. Escolhi esse poema para fazer uma breve discussão sobre a organização da oração, passando da classe de palavras, última matéria vista pela turma em que a sequência foi aplicada, para a construção de sentenças.

\section{$3^{\text {a }}$ Etapa:}

- Trabalhar com a primeira estrofe do poema, de forma conjunta com a turma, para realizar a atividade de reflexão linguística com ênfase na complementação verbal:

- Colocar no quadro uma tabela separada em "sujeito", "verbo", "complemento" e "adjunto" para preenchimento como a turma;

- Identificar os verbos; 
- Trabalhar com as intuições dos alunos para perceberem as diferentes relações entre verbos e seus argumentos, começando pelo sujeito e seguindo para o(s) complemento(s) e o(s) adjunto(s).

- Destacar no quadro os verbos de cada transitividade com cores diferentes para facilitar a assimilação dos alunos. Este último procedimento pode ser feito ao final desta etapa ou ao final da etapa 4, apresentada adiante, funcionando como uma revisão.

Orientação 1: se faltar alguma tipo de transitividade verbal no texto, dar exemplos e incluir no quadro abaixo:

Orientação 2: primeiro preencher o verbo, depois o sujeito e, por último o(s) complemento(s) e/ou adjunto(s)

Exemplo de Tabela:

Número de complementos (para entender a seleção argumental)

\begin{tabular}{|l|l|l|l|}
\hline Sujeito & Verbo & Complemento & Adjunto \\
\hline & & & \\
\hline & & & \\
\hline
\end{tabular}

\section{$4^{\text {a }}$ Etapa:}

- Focar na relação do verbo com o(s) complemento(s) - direto, indireto ou sem complemento.

- Colocar uma outra tabela no quadro separada em "verbo", "complemento direto", "complemento indireto" e "classificação - transitividade verbal";

- Colocar os verbos identificados na etapa anterior na tabela e, ainda trabalhando com a intuição deles a partir da reflexão linguística, preencher as colunas com os complementos verbais;

- Ao final, preencher a coluna da "classificação - transitividade verbal" Essa coluna só deve ser preenchida após todo o quadro estar completo, para que o aluno primeiro se conscientize do que sabe e, a partir daí, tenha acesso à nomenclatura da norma padrão. Assim, a relação entre o verbo e sua classificação será facilitada.

Exemplo de tabela

\begin{tabular}{|l|l|l|c|}
\hline Verbo & Complemento Direto & Complemento Indireto & $\begin{array}{c}\text { Transitividade } \\
\text { Verbal }\end{array}$ \\
\hline & & & \\
\hline & & & \\
\hline
\end{tabular}




\section{$5^{\text {a }}$ Etapa:}

- Pedir para que os alunos, em duplas ou em trios, sigam o mesmo processo com os verbos da parte inicial da segunda estrofe do poema fazendo uma tabela que destaque "sujeito", "verbo", "complemento", "adjunto" e "transitividade", ou seja, é a junção das tabelas das etapas 3 e 4.

\begin{tabular}{|c|c|c|c|c|}
\hline Sujeito & Verbo & Complemento & Adjunto & Transitividade Verbal \\
\hline & & & & \\
\hline & & & & \\
\hline
\end{tabular}

- Corrigir e solicitar que os alunos, agora sozinhos, repitam a atividade na parte final da segunda estrofe do poema. Fazer a correção após tempo hábil para que os alunos realizem a atividade proposta.

\begin{tabular}{|c|c|c|c|c|}
\hline Sujeito & Verbo & Complemento & Adjunto & Transitividade Verbal \\
\hline & & & & \\
\hline & & & & \\
\hline
\end{tabular}

\section{$6^{\text {a }}$ Etapa:}

- Revisão final: estabelecer relações entre o conhecimento do aluno e as transitividades verbais do dia a dia

- Pedir exemplos de frases do dia a dia que contenham as transitividades verbais estudadas;

- Escrever as frases no quadro e analisá-las;

○ Se não aparecerem durante os exemplos que os alunos derem, sugerir alguns exemplos com verbos que mudam a transitividade a depender do contexto para que os alunos percebam que não precisam gravar a matéria, mas sim refletir sobre o funcionamento da língua, compreendendo-a. Deixar isso claro.

\section{$7^{\text {a }}$ Etapa:}

- Analisar o texto abaixo que apresenta irregularidades propositalmente inseridas. Pedir para que os alunos:

o Revisem o texto identificando as irregularidades;

- Proponham uma reescrita textual de forma a sanar os problemas identificados. 


\section{TEXTO II}

"A cidade no Estado de São Paulo introduziu o toque de recolher para menores de 18 anos. O toque de recolher consiste básicamente impor um horário para que os menores de idade frequentem bares, lanchonetes, lan houses, bailes, ou seja, inibe a vida noturna desses jovens. Com o objetivo controlar os altos indices de envolvimento desses menores em transações ilícitas."

Fonte: Redação do Enem (autor oculto)

- O texto apresenta problemas de ortografia, referenciação e concordância verbal. Mostrar que essas são algumas das várias questões que temos que prestar atenção na escrita de um texto para não prejudicar sua coesão e coerência. Focar a questão da estrutura argumental que é o conteúdo da aula. 


\section{Anexo III}

\section{ESTRUTURA DA AULA TRADICIONAL}

- Ano: $3^{\circ}$ do Ensino Médio.

- Tempo de duração: 4 horas/aula

- Objetivos específicos:

○ Identificar as transitividades verbais e seus complementos.

- Objetivo final: resposta a exercícios.

\section{Tipos de verbos}

- Verbos transitivos:

- Direto(VTD): pedem complemento não preposicionado (OD).

- Indireto (VTI): pedem complemento preposicionado (OI).

- Direto e indireto (VTDI - bitransitivo): pedem OD e OI.

- Verbos Intransitivos (VI): Não pedem complemento.

- Verbos de ligação (VL): Indicam estado, qualidade ou condição do sujeito.

\section{$\underline{\text { Termos subordinados ao verbo: }}$}

- Objeto Direto: Complemento verbal de um VTD.

Exs.: Eu quero um pedaço de bolo. / Ela me esperou (Pron. Obl. Át.- esperou o João)

* Na terceira pessoa usam-se os pron. oblíquos átonos "o", "a", "o", "as" como objeto direto. Ex.: Ela o esperou.

*Objeto direto preposionado: é precedido de uma preposição, apesar de a ideia expressa pelo verbo não exigi-la.

Ex.: Eu amo a Deus com todo o meu coração. / Não odeio a ninguém. (verbos de sentimentos)

Ele beneficiava a todos a sua volta (alguns pronomes)

Cumprimentei-o e aos que com ele estavam. (reforço à clareza)

É obrigatório:

- Para evitar ambiguidade entre o sujeito e o objeto: Ex.: A onça ao caçador surpreendeu. / $\underline{\mathrm{A}}$ Felipe Marina contratou.

- Quando o objeto direto é constituído de formas pronominais. Ex.: Rubião esqueceu a sala, a mulher e a si./ Escolheu a eles seus conselheiros. 
* Objeto direto pleonástico: ocorre quando a ideia expressa pelo objeto direto é repetida (pleonasmo).

Ex.: Esse enigma, eu o passo a ti. / $\underline{\text { A correntinha, }}$ guardou-a no bolso da camisa de riscado.

OD OD VTD

- Objeto Indireto: Complemento verbal de um VTI.

Exs.: Ela $\frac{\text { desobedeceu }}{\text { VTI }} \frac{\text { às regras. }}{\text { OI }}$ / Ele $\frac{\text { me }}{\text { OI }} \frac{\text { obedece. }}{\text { VTI }}$ (Pron. Obl. Át - obedece ao João)

* Na terceira pessoa usam-se os pron. oblíquos átonos "The", "Thes" como objeto indireto.

Ex.: Ele lhe obedece.

* Objeto indireto pleonástico: ocorre quando a ideia expressa pelo objeto indireto é repetida (pleonasmo).

Ex.: Às violetas, não thes poupei água.

OI OI VTDI

- Agente da passiva: Termo que, na voz passiva, realiza a ação verbal que o sujeito sofre.

Exs.: A História é feita por grandes homens. / Os jovens ficam entusiasmados com essas ideias.

- Adjunto adverbial: Termo complementar circunstancial. É acessório, ou seja, aparece apenas para indicar uma circunstância à ação verbal. É a função própria do advérbio, das locuções e das expressões adverbiais. Exs.:

A maçã caiu da árvore. (lugar)

Ontem fui ao cinema (tempo)

O menino morreu de fome. (causa)

Ele falou conosco sobre sua mulher. (assunto)

Ele veio a pé. (meio)

Ele falou com calma. (modo)

Ele fala muito bem. (intensidade)

Talvez ele seja escritor. (dúvida)

Queria passear contigo. (companhia).

Ele cortou a mão com a faca (instrumento).

\section{Exercícios}

1 - Considere a frase: "Ele andava triste porque não encontrava a companheira", os verbos grifados são respectivamente:

a) transitivo direto - de ligação;

b) de ligação - intransitivo;

c) de ligação - transitivo indireto;

d) transitivo direto - transitivo indireto;

e) de ligação - transitivo direto. 
2 - Todas as orações apresentam verbo de ligação, exceto:

a) Camilo saiu desesperado da biblioteca.

b) Juliana ficou pensativa ao lado da irmã.

c) Orestes continuava firme no seu propósito.

d) Jairo permanece calado no meio da gritaria.

e) Cézar parecia um rapaz entre seus coleguinhas.

3 - No período "Cumpriria com as obrigações, certamente". A função sintática do elemento sublinhado é:
a) complemento nominal;
b) objeto direto;
c) objeto direto preposicionado;
d) objeto indireto;
e) adjunto adverbial.

4 - "O toque dos sinos ao cair da noite era trazido lá da cidade pelo vento". O termo grifado é:
a) sujeito;
b) objeto direto;
c) objeto indireto;
d) complemento nominal;
e) agente da passiva.

5 - $\mathrm{O}$ verbo em destaque foi incorretamente analisado em:

a) Acordei no meio da noite e pensei em você. (Verbo transitivo indireto)

b) Ela estava animada ontem. (Verbo de ligação)

c) Todos brincavam no quintal. (Verbo transitivo indireto)

d) Pedi a conta e saí do restaurante. (Verbo intransitivo)

e) A criança não comia salada. (Verbo transitivo indireto)

6 - Assinale o único caso em que o pronome oblíquo átono exerce a função de objeto indireto:

a) Contive-me.

b) Ele aguardava-me desde cedo.

c) Isto me agrada.

d) $\mathrm{O}$ aluno me viu.

e) Socorram-me.

7 - Assinale a opção correta quanto à predicação atribuída ao verbo sublinhado na passagem do texto.

a) "A casa fica num alto lavado de ventos." - ligação;

b) "Aqui não há encantos." - intransitivo; 
c) "... as zínias e os manjericões que levantavam um muro colorido ao pé dos estacotes" - transitivo direto e indireto;

d) "Sim, só comparo o Nordeste à Terra Santa." - intransitivo;

e) "... em torno do qual gravitam as plantas, os homens e os bichos." - intransitivo.

8 - Identifique a alternativa em que há objeto direto preposicionado:

a) Passou aos alunos, para estudo, o texto impresso.

b) Naquela época, era difícil viajar para a Europa.

c) Em dias chuvosos, gosto de ler um bom livro.

c) Sentamo-nos numa das mesas e pedimos o jantar.

d) Amou a João com o mais puro amor.

9 - No período: "As cartas, enviei-âs, ontem, pelo portador da Companhia." A função sintática do termo sublinhado é:

a) objeto indireto pleonástico;

b) sujeito;

c) objeto indireto;

d) objeto direto pleonástico;

e) objeto direto.

10 - Tendo como referência os termos em destaque, relacione a $2^{\mathrm{a}}$ coluna de acordo com a primeira:

a - Quando chegares do trabalho avise-me.

$\mathrm{b}-\mathrm{O}$ discurso do diretor foi aplaudido com entusiasmo.

c - Visitaremos o litoral nordestino nestas férias.

d - Como chovia bastante, não fomos ao cinema, conforme combinado.

e - Fiquei muito agradecida pela sua ajuda.

( ) adjunto adverbial de intensidade

( ) adjunto adverbial de lugar

( ) adjunto adverbial de modo

( ) adjunto adverbial de causa

( ) adjunto adverbial de tempo 


\section{Anexo IV}

\section{ATIVIDADE AVALIATIVA}

Sabendo que a criatividade linguística permite uma infinidade de combinações e possibilidades para a língua e que, mesmo com o advento da tecnologia, a escrita se mantém firme, temos a regularidade linguística como uma característica imprescindível para a gramática da língua e para uma escrita coesa e coerente. Diante disso, atente-se para as atividades a seguir. Siga as instruções.

\section{Questão 1}

Leia o texto abaixo e siga as seguintes etapas:
a) Encontre as orações;
b) Identifique os verbos;
b) Reflita sobre seus argumentos;
c) Complete a tabela.

\section{TEXTO I}

"Desde que o homem organizou o pensamento por meio de registros, a escrita ganhou extrema relevância nas relações sociais, na difusão de ideias e informações. Ela ficou ameaçada com o advindo do telefone, da televisão e do cinema, mas logo recuperou sua força com a internet, o e-mail, o blog, o twitter. Quem a ignora está fora do mundo".

Fonte: Educar para crescer (adaptado). Disponível em: $<$ http://educarparacrescer.abril.com.br/comportamento/importancia-es crita-559518.shtml>.

\begin{tabular}{|l|l|l|l|l|}
\hline Sujeito & Verbo & Complemento & Adjunto & Transitividade Verbal \\
\hline & & & & \\
\hline & & & & \\
\hline & & & & \\
\hline & & & & \\
\hline & & & & \\
\hline & & & & \\
\hline
\end{tabular}




\section{Questão 2}

Revise o texto abaixo e use seu conhecimento sobre a estrutura linguística das orações para completar a tabela.

\section{$\underline{\text { TEXTO II }}$}

"A ONU apresentouhoje à primeira universidade global em linha e de matricula gratuita. Essa atitude impulsionará ao acesso à educação superior dos estudantes das regiões menos desenvolvidas do mundo. (...) Os únicos gastos para os alunos são uma matrícula entre 15 a 50 dólares por cada exame."

Disponível em: https://ciberduvidas.iscte-iul.pt/consultorio/perguntas/ exemplos-sobre-incoerencia-e-falta-de-coesao-nas-frases/27361

\begin{tabular}{|l|l|l|l|l|}
\hline Sujeito & Verbo & Complemento & Adjunto & Transitividade Verbal \\
\hline & & & & \\
\hline & & & & \\
\hline & & & & \\
\hline
\end{tabular}

Há problemas na regularidade do texto? ( ) Sim （） Não

Havendo problema, relate, pelo menos, dois aspectos problemáticos do texto:

Dicas: encontre os verbos, verifique os complementos dos verbos, reflita sobre 0 sentido dos verbos e sobre a relação que tais verbos mantém com seus argumentos. Também vale se atentar para questões como impropriedade vocabular, falta de clareza, etc.

a)

b)

\section{Questão 3}

Faça uma proposta de reescrita do texto II de modo a sanar os problemas identificados, tornando a escrita mais coesa e coerente. 


\section{Anexo V}

\section{AVALIAÇÃO DA PROPOSTA PEDAGÓGICA}

Levando em consideração a abordagem do assunto apresentado e as atividades propostas, responda:

1. A atividade foi apresentada de forma interessante, gerando motivação para aprender o assunto?
( ) SIM
( ) NÃO

2. A atividade tem um nível de dificuldade condizente com seus conhecimentos?
( ) SIM
( ) NÃO

3. A atividade facilitou a aprendizagem do assunto?
( ) SIM
( ) NÃO

4. A atividade acrescentou conhecimento útil para você?

( ) SIM ( ) NÃO

5. A atividade poderia ser apresentada de outra forma? Qual?

( ) SIM ( ) NÃO

Comentários e/ou sugestões 